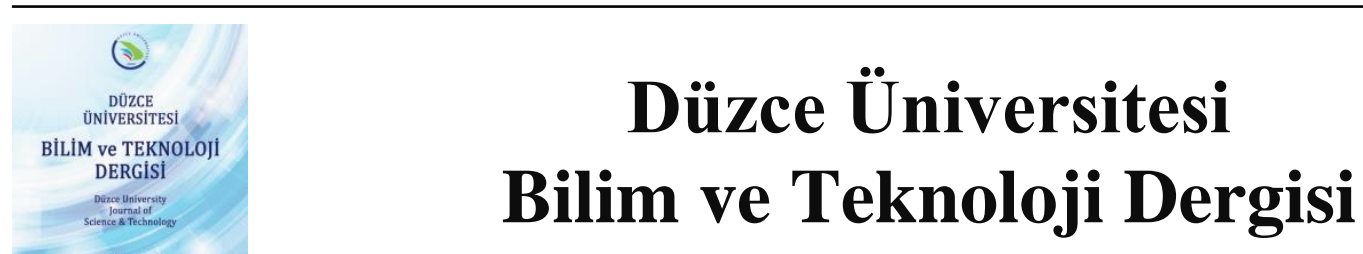

Araştırma Makalesi

\section{Yeniden İşlevlendirme Uygulamalarında Özgünlük Kayıplarının Araştırılması: Geleneksel Alanya Konutları Örneği}

\author{
(iD Nazmiye Gizem ARI ${ }^{a}$, (iD) M. Elif ÇELEBİ KARAKÖK ${ }^{b, *}$ \\ ${ }^{a}$ Mimarlık ve Şehir Planlama Bölümü, Akseki MYO, Alaaddin Keykubat Üniversitesi, Alanya, TÜRKIYE \\ ${ }^{b}$ Mimarlık Bölümü, Mimarlık Fakültesi, Akdeniz Üniversitesi, Antalya, TÜRKIYE \\ * Sorumlu yazar: M. Elif ÇELEBİ KARAKÖK, e-posta adresi: elifcelebi@akdeniz.edu.tr
} DOI: 10.29130/dubited.910812

\begin{abstract}
$\underline{\mathrm{O} Z}$
Kent merkezlerindeki tarihi dokularda günümüzde rant marjları çok yükselmiş, tarihi yapılara turizm ve ticaret işlevleri verme eğilimi artmıştır. Yeniden işlevlendirme adı verilen bu uygulama aslında terk edilmiş ya da özgün işlevini devam ettirmesi mümkün olmayan yapıları, yeni bir işlevle kullanımını sağlayarak gelecek kuşaklara aktarmak için geliştirilmiş bir koruma yöntemidir. Ancak bu yöntem günümüzde sanki bir tasarım modeli gibi kullanılarak tarihi yapıların özgün değerlerinden çok fazla kayıplara neden olmaktadır. Koruma yasasındaki esneklik, sayısal nicelik ve şahıs mülkiyetlerinde olmaları gibi sebeplerle yeniden işlevlendirilerek özgünlük değerlerinden en çok kayıplar veren yapılar geleneksel konutlardır. Tarihi yapılar ve bu yapıların oluşturduğu tarihi çevre, bölgeye özgü fiziksel ve kültürel özellikler sonucu oluşmuş geleneksel mimari örneklerdir. Özellikle geleneksel konutlar bulunduğu bölgedeki günlük yaşam ve kültürü hakkında önemli veriler sunan tarihi belgelerdir. Bu nedenle diğer tarihi yapılar gibi geleneksel konut yapılarının da özgünlüklerinin korunması ve gelecek kuşaklara aktarılması önem arz etmektedir. Yeniden işlevlendirme ile özgün değerlerini yitiren tarihi çevrelerden birisi de Antalya'nın önemli turizm merkezlerinden birisi olan Alanya'dır. Bu nedenle bu çalışmada yeniden işlevlendirme ile restorasyonu yapılan geleneksel Alanya konutları çalışma alanı olarak seçilmiş, bu bölgedeki uygulamaların olumlu ve olumsuz yönleri ortaya konularak tartışılmıştır.
\end{abstract}

Anahtar Kelimeler: Geleneksel Konut, Mimari Koruma, Yeniden İşlevlendirme, Özgünlük, Alanya.

\section{Investigation of Loss of Originality in Re-Functioning Applications: The Case of Traditional Alanya Houses}

\begin{abstract}
In the historical textures of the city centers, the income margins have increased significantly and the tendency to give tourism and trade functions to historical buildings has increased. This practice, called re-functioning, is actually a protection method developed to transfer abandoned or useless functions to future generations by using them with a new function. However, this method is used as a design model today, causing much loss of the original values of historical buildings. Traditional houses are the structures that give the most loss of originality by re-functioning due to the flexibility in the law, numerical quantity and the fact that privately owned. Traditional houses are historical documents that provide important data about daily life and culture in the region where they are located. For this reason, it is important to preserve the authenticity of traditional residential buildings like other historical buildings. One of the historical circles that lost their original values through refunctioning is Alanya, which is one of the important tourism centers of Antalya. For this reason, traditional Alanya residences, which were restored by re-functioning, were chosen as the study area, and the positive and negative aspects of the applications were discussed.
\end{abstract}

Keywords: Traditional House, Architectural Preservation, Re-functioning, Originality, Alanya.

Geliş: 06/04/2021, Düzeltme: 19/05/2021, Kabul: 27/05/2021

* Bu çalışma "Yeniden İşlevlendirme Uygulamalarında Özgünlük Kayıplarının Araştırılması: Geleneksel Alanya Konutları Örneği” başlıklı ve devam etmekte olan doktora tezinden türetilmiştir. 


\section{GIRIS}

Geleneksel yapı, sanayi öncesi toplumlardaki yerel yapı ustalarının inşaat becerilerine ve geliştirdikleri bilgilere dayanarak taş, toprak, ahşap gibi doğadan elde edilen malzemelerle inşa edilen bir yapılaşma modelidir. İnşa edildiği coğrafyadaki halkın kültürüne, iklime, ulaşılan doğal malzemeye, topoğrafik düzene ve yaşam koşullarına göre çeşitlilik gösterir [1]. İnşa teknolojilerinin ait olduğu dönemlerde yapılmış olan geleneksel yapılar, aynı zamanda tarihi yapı niteliği taşırlar. Bu yapılar ait oldukları dönemin mekân, yapım sistemi, malzeme, bezeme vb. özelliklerinin birer belgesidirler. Geçmişin bilgi ve tecrübesini günümüze aktarırlar.

Geleneksel yapılar hem kamu hem sivil mimarlık yapıları olabilir. Ancak sayısal nicelikle birlikte mimari çeşitlilik en çok konut yapılarında görülür. Konutlardaki bu farklı biçimlenişler iklim, coğrafya ve ulaşılan malzeme gibi fiziksel; günlük yaşam ve aile yapısı gibi sosyal; gelenek, inanç ve töre gibi kültürel; tarım, hayvancılık, dokumacılık gibi sosyo-ekonomik faktörler etkisinde gelişmiştir [2]. Bu nedenle geleneksel konutlar, sanayi devrimi öncesi yaşamın ve kültürün aynası görevini görürler.

Ancak ülkemizde geleneksel konut yapıları koruma yasasındaki esneklik, sayısal nicelik ve şahıs mülkiyetinde olmaları gibi nedenlerle kullanıcıları tarafından çok fazla yapısal müdahaleye maruz kalmaktadırlar. Müdahalelerin niteliği ve niceliği, yapıların özgünlüğünü ${ }^{1}$ bozarak tarihi belge niteliğini kaybetmesine ve bu nedenle geleneksel konutların kültür varllğı yasal koruma statüsünü alamamasına veya bu statüden çıkarılmasına neden olabilmektedir. Bu nedenle geleneksel konut yapılarının özgünlügünün ${ }^{2}$ korunamaması günümüzde oldukça önemli bir sorun haline gelmiştir.

Kullanıcılar, eski teknolojiye göre yapılmış bu yapılara günümüz konfor koşullarını getirmek ve / veya bulundukları bölgedeki yükselen rant değerlerinden daha fazla faydalanabilmek amaciyla, yapıların özgün mimari özelliklerini büyük ölçüde değiştirmektedirler. Rant değeri yükselen bölgelerdeki konutların yeniden işlevlendirilerek ticaret ya da turizm yapılarına dönüştürüldüğü çok s1k görülmektedir.

Aslında yapıları, özgün işlevleri dışında kullanmak antik çağlardan günümüze kadar uygulanan bir yöntemdir [5]. Özgün işlevi ile varlığını sürdüremeyen yapıları farklı işlevlerle kullanma yöntemiyle, yapılar yıkılmaktan kurtulmuştur ve böylece eski yapılar günümüze kadar ulaşabilmiştir [6]. Ancak çağdaş koruma kuramlarına göre yeniden işlevlendirmede de esas amacın yapıyı özgün haliyle yaşatmak olduğu unutulmamalı ve yapının özgünlüğüne zarar verecek işlev ve müdahalelerden kaçınılmalıdır. Korunacak yapı için yeni işlev belirlenirken yapının kurgusu ile özgün yapım tekniğinin ve elemanlarının oluşturduğu mimari değerine olumsuz etki etmemesi için yapının mimari kimliği, kütlesel bütünlüğü, bulunduğu çevre ve etkileşimde olduğu diğer kentsel mekanlarla ilişkisi detaylıca analiz edilerek değerlendirilmelidir. Yeni işlev, sürdürülebilirlik ve kullanılabilirlik açısından korumaya katkıda bulunmalıdır [7].

Geleneksel Alanya Konutları da bölgede her geçen gün yükselen rant marjları nedeniyle sahipleri ve yatırımcıların gözdesi haline gelmiş̧ir. Birçok konutun yeniden işlevlendirme yöntemi ile turizm veya ticaret yapılarına dönüştürüldükleri görülmektedir. Yeni işlevlerin sahip olması gerektiği düşünülen günümüz konfor koşullarını sağlayan mekân ve tesisatlarla ilgili müdahaleler yapılmaktadır. Ancak

\footnotetext{
${ }^{1}$ Feilden ve Jokiletho özgünlüğü, "inşa edildiği ve zaman içinde yaşlandığı ve yıprandığı haliyle maddi olarak orijinal veya orijinal bir miras kaynağına atfedilen" bir nitelik olarak tanımlamıştır. Özgünlük, yapının kendi zamanının gerçek bir ürünü olarak üretilen yaratıcı sürecin ve tarihsel zamandan geçişinin etkilerini içerir [3].

${ }^{2}$ Uluslararası Anıtlar ve Sitler Konseyi (ICOMOS), 1994 yılında yayınladığı Nara Özgünlük Belgesinde kültür varlıklarının özgünlüğünün içerdikleri bilgi kaynaklarına bağlı olduğunu belirtmiştir. Bu bilgi kaynaklarını da "tasarım ve biçim, malzeme ve nesne, kullanım ve işlev, gelenek ve teknikler, konum ve yerleşim, ruh ve anlatım ile tarihsel evrim olarak açıklamıştır [4]. Nara Özgünlük Belgesinde belirtilen bilgi kaynaklarına bakıldığında özgünlük kavramının çerçevesinin genişliği kolayca anlaşılabilmektedir.
} 
yeni işlevin sahip olması gerekenlere çok fazla odaklanıldığı, bu uğurda konutların özgünlüğünden önemli derecede kayıplar verildiği düşünülmektedir.

$\mathrm{Bu}$ nedenle, Alanya'daki geleneksel konutların özgün mekânsal ve yapısal nitelikleri incelenmiş, yeniden işlevlendirme uygulamalarındaki sorunlar tespit edilmiş ve tartışılmıştır. Böylece geleneksel konutların korunması çalışmalarında özgünlük değerlerini yok etmeden gelecek kuşaklara aktarılmalarına ve sosyo - kültürel olarak sürdürülebilirliklerini sağlamaya katkıda bulunmak hedeflenmiştir.

\section{YÖNTEM}

Çalışma konusu geleneksel konutların yeniden işlevlendirme uygulamalarındaki özgünlük kayıplarının araştırılması olduğu için, elde edilecek verilerin hayata geçirilmiş uygulamalar üzerinden toplanmasına karar verilmiştir. Geleneksel konutların yeniden işlevlendirilmesi uygulamaları, özellikle turizm sektörünün ağır bastığı yerleşimlerde görüldüğü için, seçilen çalışma alanının da bir turizm bölgesi olması tercih edilmiştir. Uygulamaların bağlı oldukları şartları bir denge çerçevesinde değerlendirebilmek için de seçilen örneklerin aynı konumda olmaları gerektiği düşünülmüştür. $\mathrm{Bu}$ nedenle çalışmada bir turizm kenti olan Antalya'nın Alanya ilçesinin tarihi dokusundaki uygulamalar ele alınmıştır.

Bu kapsamda Alanya'da yeniden işlevlendirme yöntemi kullanılarak restore edilen 8 adet geleneksel konut yapısı incelenmiştir. Seçilen örneklerin yeni işlevlerinin farklı olmasına dikkat edilmiştir. Böylece hangi işlevin ne gibi değişikliklere neden olduğu da gözlemlenmek istenmiştir. Bu kriterler 1şığında 2 adet ofis işlevli (Hasanağalar Konağı, Çırpanlı Konutu), 2 adet konaklama işlevli (Sezer Konutu, Şimşek Konutu), 2 adet kafe/restoran işlevli geleneksel konut (Durusoy Konutu, Sipahioğlu Konutu) ile 2 adet işlevi değiştirilmemiş geleneksel konut (Kök Konutu, Gürses Konutu) incelenmiştir.

Öncelikle restitüsyon projeleri üzerinden yapıların özgün mimari özellikleri tespit edilmiştir. Özgün plan şemaları, yapım tekniği ve malzeme, cephe karakteri, bezeme programı, renk, bahçe - peyzaj düzeni vb. özellikleri incelenmiştir. Ardından bu geleneksel konutların yeniden işlevlendirilerek kullanılan durumları analiz edilmiştir. Bu analizler yapıların restorasyon projelerinden ve yapının kendisinden elde edilen veriler ile yapılmıştır. Yeniden işlevlendirme öncesi ve sonrası özgünlük ve değişiklik durumu, karşılaştırmalı olarak irdelenmiştir.

Karşılaştırma yönteminin sağladığı veriler üzerinden hangi yapıda ne gibi özgünlük kayıplarının yaşandığı, yapılan değişiklikler, eklenen ve kaldırılan ögeler gibi olumsuz etkilerin yanı sıra günümüz konfor koşullarının sağlanması ve yapının kullanımının sürdürülmesi gibi olumlu etkiler de tartışılmıştır. Bu çalışmanın geleneksel konutların yeniden işlevlendirilmesi uygulamalarına katkı sağlayacağ 1 düşünülmektedir.

\section{ALANYA ILCESI'NIN TARIHI VE KENTSEL GELISSSIMI}

Alanya, Akdeniz Bölgesi'nde Antalya iline bağlı bir ilçedir. Kuzeyde Gündoğmuş, batıda Manavgat, doğuda Gazipaşa, kuzeydoğuda Konya ili ile komşudur. Antalya'nın yaklaşı olarak $135 \mathrm{~km}$ doğusunda, Akdeniz kıyısında konumlanmıştır (Şekil 1) [8]. Alanya'daki ilk yerleşim Toros dağları ile Akdeniz arasındaki düzlükte iken, zaman içerisinde kuzeydeki yamaçlara doğru gelişme göstermiştir. Kentsel gelişimini, iklim özellikleri de doğrudan etkilemiştir. Yazları sıcak ve kurak, kışları 1lık ve yağışlı geçen Akdeniz iklimi, Alanya'nın oldukça tercih edilen ve sürekli büyüyen bir yerleşim merkezi haline gelmesinde rol oynamıştır. Bulunduğu coğrafya ve iklim özelliklerinin etkisiyle tarım 
ve turizm sektörünün etkinliği baskın olarak görülmektedir. 1980'li yıllardan bu yana turizmin hızla geliştiği bir yerleşimdir [9].

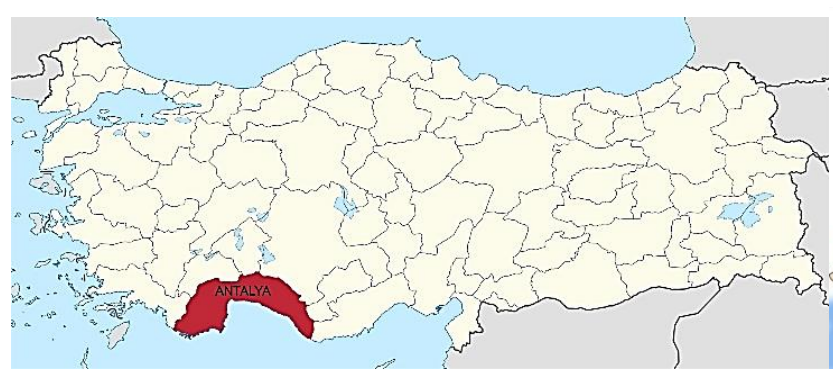

(a)

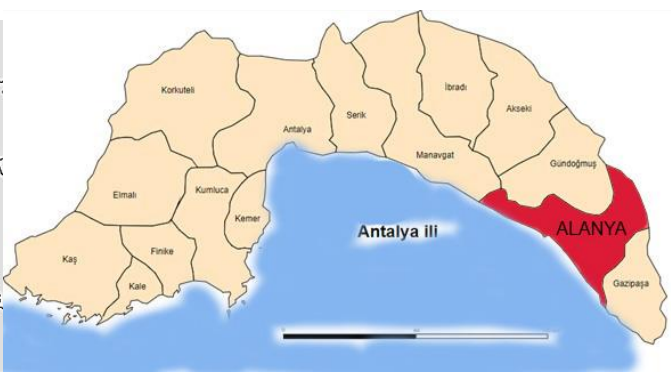

(b)

Şekil 1. (a) Türkiye'de Antalya ili [8] ve (b) Antalya'da Alanya ilçesinin Konumu [9].

Şehir, gelişim düzenine göre incelendiğinde sosyo-ekonomik, kültürel ve tarihi değişikliklere dayalı üç dönüm noktası ile karşılaşılmaktadır. Bunlardan birincisi şehrin sur duvarları içinden kuzeydeki düzlük alana yayıldığı 1860 öncesi yıllar, ikincisi gelişen turizm ile şehrin kuzey etekler boyunca yayıldığı 1960lı yıllar, üçüncüsü ise 1960'lı yıllardan günümüze kadar olan dönemdir [9]. Alanya tarihi dönüm noktaları ile genişlediği üç bölgede "birinci, ikinci ve üçüncü" yerleşim alanları olarak gruplandırılmıştır (Şekil 2) [10].

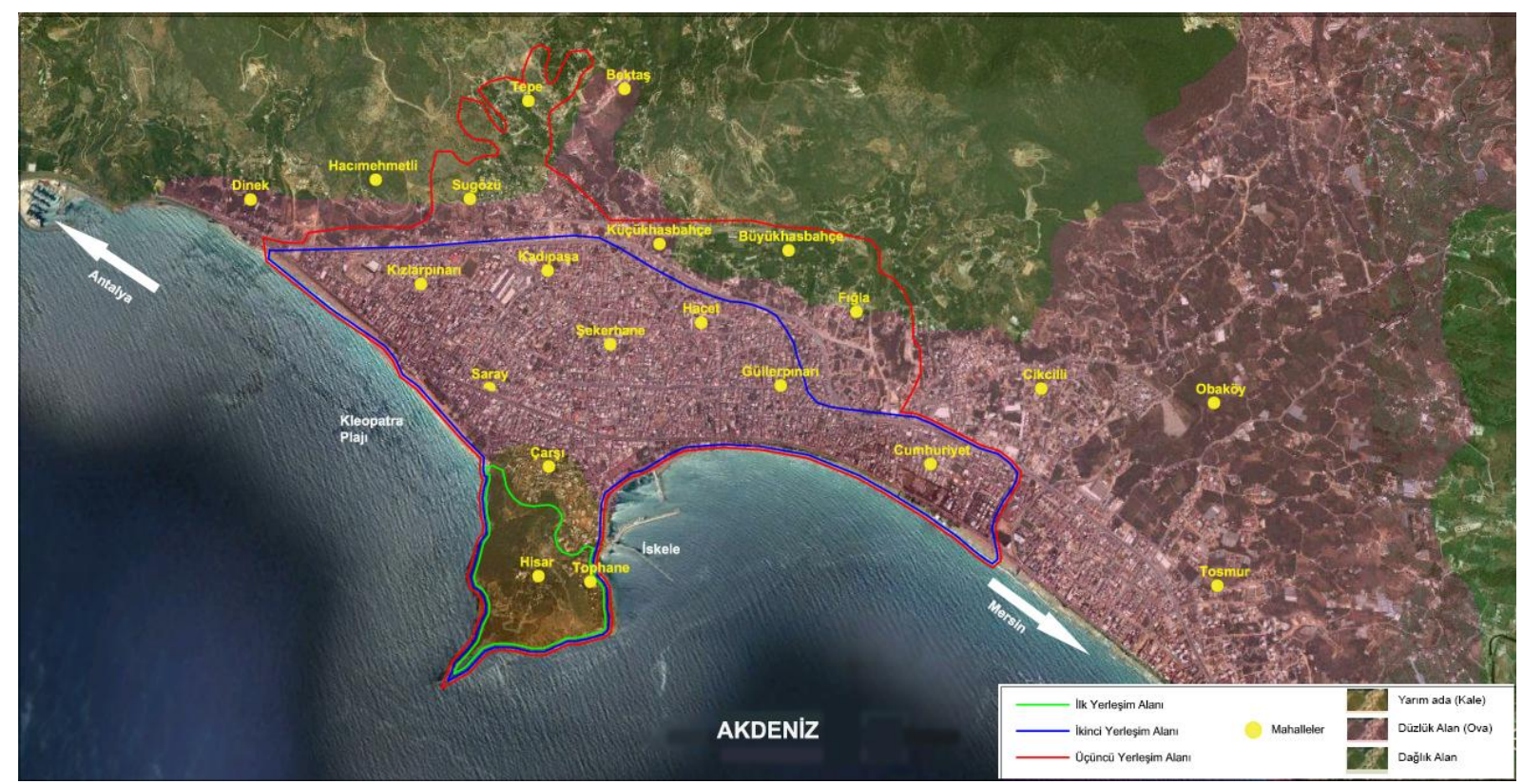

Şekil 2. Alanya tarihsel yerleşim paftası [10].

\section{A. BİRINCI YERLEŞIM ALANI}

Birinci Yerleşim Alanı, surlarla tanımlı olan alandır (Şekil 2, yeşil renkle sınırlı alan). Bu alan şehrin en eski yerleşik alanıdır. Alanya Kalesi ve iki mahalleyi (Hisariçi ve Tophane) kapsamaktadır. Birinci derece arkeolojik, kentsel, doğal ve tarihi sit alanı olarak korunan Alanya Kalesi, 2000 yılından bu yana Dünya Miras Listesi’nin geçici listesinde yer almaktadır. Koruma çalışmaları tamamlanmış, Kızılkule-Tophane ekseni marina ve gemi müzesine dönüştürülmüş, bölgedeki anıtlar onarılmıştır. 
Bu alanda 76 adet (39 adet anıtsal yapı, 27 adet konut ve 10 adet harabe) tescilli yapı bulunmaktadır. Geleneksel konutların çoğu özgün işlevinde kullanılmaktadır. Küçük bir kısmı ise kahve, lokanta ya da alışveriş birimine Dönüştürülmüştür. Konutların çoğunluğu restore edilmiştir [10].

\section{B. İKİNCI YERLEŞiM ALANI}

İkinci Yerleşim Alanı, 1860'lar sonrası yerleşilmiş olan ve Çevre Yolu Caddesi ve Yarımada arasında kalan düzlük alandır (Şekil 2, mavi renkle sınırlı alan). Bu bölge yedi mahalleden oluşmaktadır (Çarşı, Kızlarpınarı, Kadıpınarı, Şekerhane, Saray, Hacet ve Güllerpınarı). Bölgede tescilli 73 kültür ve tabiat varlığı (5 anıt, 65 konut, 1 ticari yapı, 1 şelale, 1 mezarlık ve 1 mağara) mevcuttur. Ayrıca bölgede Geç Antik ve Roma kalıntılarını içeren bir üçüncü derece arkeolojik sit alanı vardır (Şekil 2).

Bölgedeki geleneksel evler, genellikle 1890- 1930 yılları arasında inşa edilmiştir. Ancak bu bölge 1860 sonrası bir gelişim alanı olduğu için, geleneksel konutlar yeni yapıların arasında kalmıştır. Yaklaşık olarak bölgedeki geleneksel konutların 20 adedi terk edilmiş, 20 adedinin üst katları konut işlevini sürdürürken alt katlar ticari amaçla kullanılmaktadır. Bu evlere kafe, restoran veya dükkân olarak yeniden işlev kazandırmaya yönelik genel bir eğilim söz konusudur. Yaklaşık 20 geleneksel konut da özgün işlevinde kullanılmaktadır. Geleneksel konutların yaklaşık 30 adedi restore edilmiştir (Şekil 3) [10].

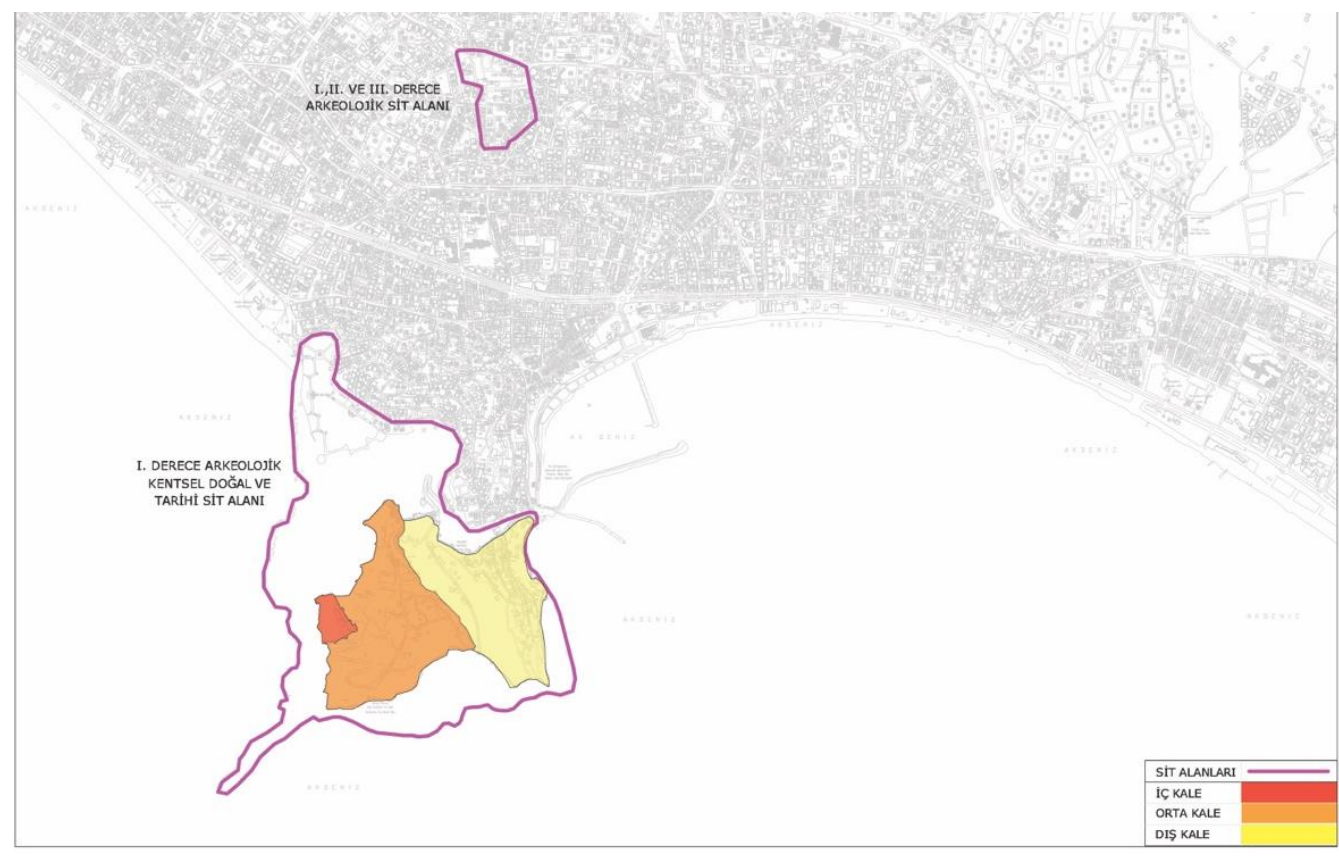

Şekil 3. Alanya sit alanlart ve tarihi yapılar paftası [10].

\section{C. ÜÇÜNCÜ YERLEŞIM ALANI}

Çevre Yolu Caddesi ve ilçenin kuzey sınırları içinde kalan bölge, Üçüncü Yerleşim Bölgesi olarak adlandırılmıştır (Şekil 2, kırmızı renkle sınırlı alan). Üçüncü Yerleşim Bölgesi, dokuz mahalleden (Dinek, Hacımehmetli, Tepe, Sugözü, Küçükhasbahçe, Büyükhasbahçe, Fığla ve Cikcilli) oluşmaktadır.

Bölgede iki adet (1 anıt, 1 konut) tescilli yapı mevcuttur. Geleneksel teknikler ile inşa edilmiş birkaç konut olmasına rağmen, yalnızca bir tanesi yasalar tarafından korunmuştur [10]. 


\section{ALANYA GELENEKSEL KONUT MIMARISİ ÖZELLIKLERI}

Sultan Birinci Alâeddin Keykubad'ın Alanya'yı fethinden sonra imar çalışmaları için birçok yapı ustası şehre getirilmiştir. 1221-1922 yılları arasında şehrin imarında çalışan Rum ve Türk yapı ustaları tarafindan geleneksel Alanya konut tipi geliştirilmiştir.

Alanya geleneksel konutları genellikle iki katlıdır. Bölgenin eğimli yapısı nedeniyle belli bir kot seviyesinin altında kalan mekanlar oluşmuştur. Bu mekanlar çoğunlukla hayvan barınağı ya da fazla eşyaların depolandığı hacimler olarak kullanılmıştır ve "gedey" olarak adlandırılmıştır. Üst katlarda ise aile yaşamının geçtiği mabeyn, hayat, içeri (küçük/büyük), şahnişin (çağnişir) ve mutfak mekanları bulunur. Çağnişir denilen ve günümüz oturma odasına karşılık gelen mekân evlerin en kıymetli bölümüdür. Konut içinde yer alan eylemlerin gerçekleştirildiği hacimlerden hayat, çağnişir, mabeyn ve çardak hacimlerini manzara yönünde yer alan bir dilim içinde, ebeveyn yatak odası (büyük içeri), mutfak ve bazen küçük içeri hacimleri ise bir önceki dilimin gerisinde yer alan başka bir dilim içinde bulunmaktadırlar. Hela ve abdestlik hacimleri her iki dilim içinde de yer alabilmektedir. Ilıman iklimin etkisi ile kapalı mekanlar kadar açık ve yarı açık mekanlara da yer verilmiştir (Şekil 4) [11].

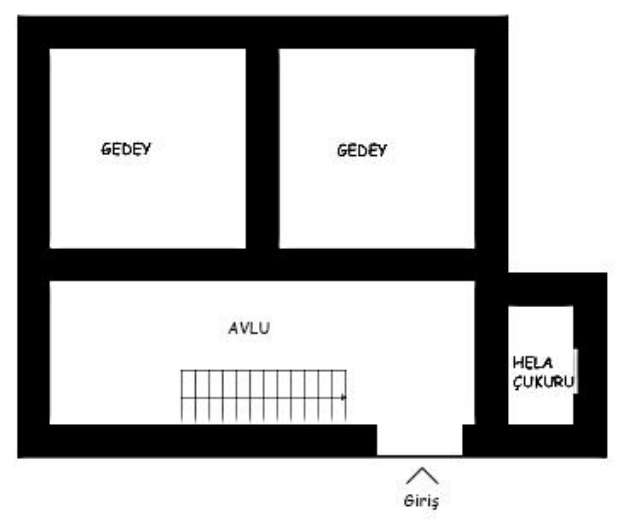

Zemin kat krokisi

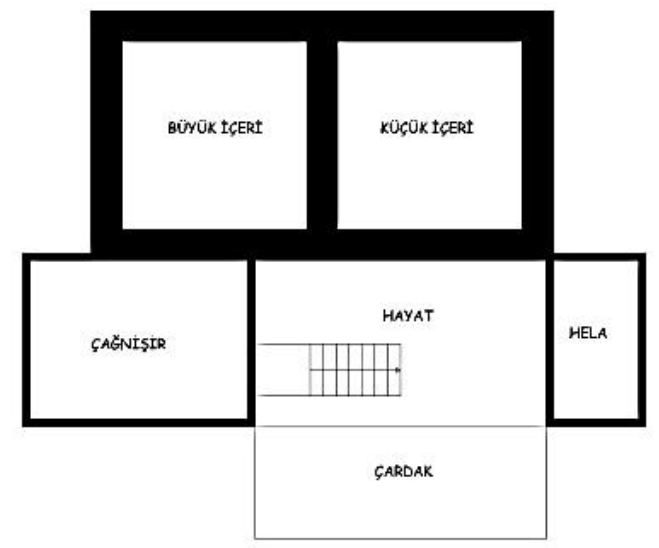

Birinci kat krokisi

(b)

Şekil 4. Alanya geleneksel konutlarında mekanların yerleşim krokisi (a) Zemin kat planı ve (b) Üst kat planı.

Mevsimsel ayırım etkeninin ağırlı̆̆ 1 göz önünde tutularak hayat, çağnışır, mabeyn, küçük içeri ve çardak hacimlerinin bulunduğu manzara yönündeki dilimi "yazlık dilim"; ebeveyn yatak odası (büyük içeri), mutfak ve bazen de küçük içeri hacimlerinin bulunduğu dilimi "kışlık dilim" olarak tanımlamak mümkündür (Şekil 5) [11]. 


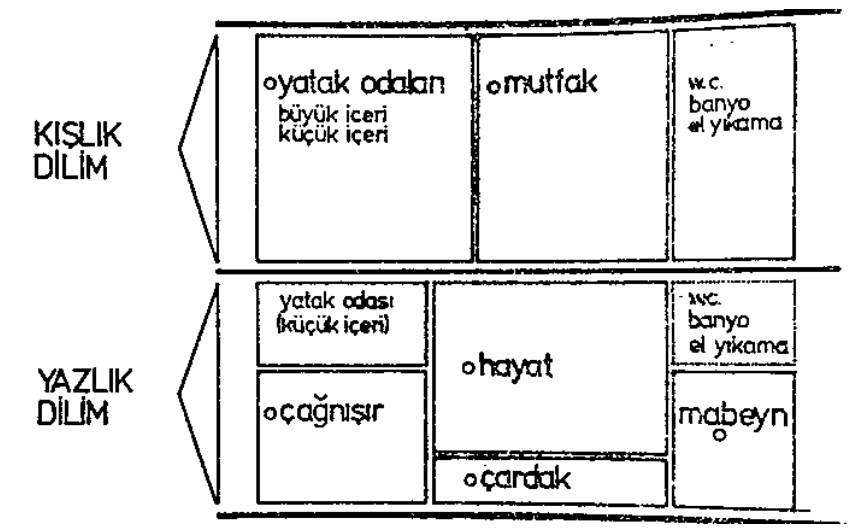

Şekil 5. Alanya geleneksel konutlarının ortak özellikteki mekânsal dă̆llım şeması [10].

Yapım malzemesi olarak bölgede bulunabilen taş ve ahşap malzeme tercih edilmiştir. Alt katlarda ahşap hatıllı moloz taş duvar, üst katlarda ahşap bağdadi duvar teknikleri kullanılmıştır. Bağdadi duvarlar kıtıklı sıva ile sıvanmıştır. Manzara yönündeki dilim (yazlık dilim), genel olarak zemin kat boyunca yükselen taşıyıcı ahşap dikmeler üzerine ahşap karkas sistemde inşa edilmiştir. Bu bölüm ahşap elemanlarla kaplanmış veya kıtık sıva ile sıvanmıştır. Çatı genellikle eğimlidir ve alaturka kiremit ile örtülüdür. Diğer dilim (kışlık dilim), zemin ve üst katta taşıyıcı taş duvarlar (ahşap hatıllı, dışta sıvasız, içte sadece yaşama katında sıvalı) ve genellikle sıkıştırılmış killi toprak örtülü düz çatı (dam) olarak oluşmuştur [11].

Yapılarda uygulanan geleneksel yapım teknikleri, cephelerde de rahatlıkla gözlenebilmektedir. Zemin katlar moloz taş duvar ile inşa edilmiştir. Birinci katlarda manzaraya bakan cepheler bağdadi (yazlık dilim), yamaca bakan cepheler ise moloz taş (kışlık dilim) kullanılarak yapılmışlardır. Zemin katların ahır veya depo olarak kullanılmasından dolayı pencere sayısı az, küçük ve demir parmaklıdır. Bazı yapılarda ise pencere bulunmamaktadır (Şekil 6). Cephelerde süsleme, yap1 elemanlarıyla sağlanmıştır. En dikkat çekici cephe birinci katın manzaraya bakan kısmıdır. Bu bölüm ahşap söveli, dört ayrı ahşap kapağı ve yöreye özgü demir parmaklıkları olan büyük pencereli kısımdır. Bazı yapılarda bu cephede yer alan pencerelerin üzerinde küçük boyutlu tepe pencereleri yer alır. Farklı tekniklerle yapılmış pencere kapakları dikkat çeken bir diğer yapı elemanlarıdır [12].

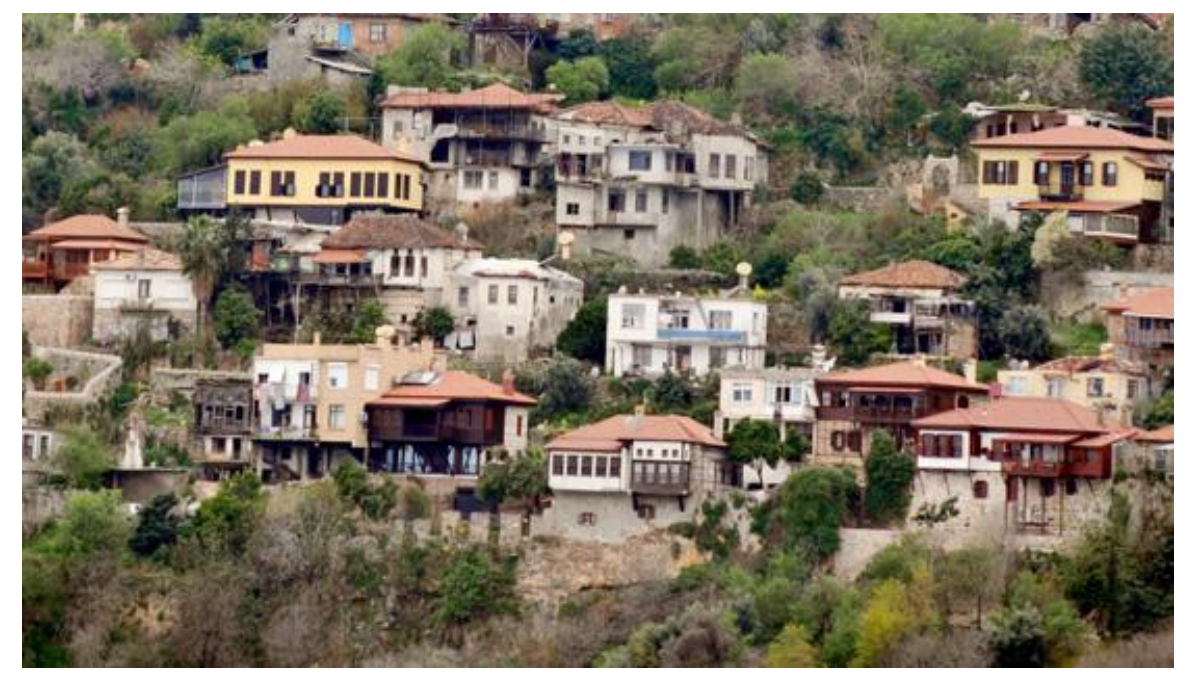

Şekil 6. Tarihi dokuyu oluşturan Alanya Geleneksel konutlarında cephelerin genel görünümü. 


\section{YENIDEN ISLEVLENDIRILEN GELENEKSEL ALANYA EVLERI}

İlçedeki farklı işlevlerde kullanılan geleneksel konutlar incelendiğinde bu yapıların konaklama, yeme içme ve ofis işlevleri ile kullanıldıkları görülmektedir. Ofis olarak yeniden işlevlendirilen Hasanağalar Konağı ve Çırpanlı Konutu; konaklama amaçlı yeniden işlevlendirilen Sezer Konutu ve Şimşek Konutu; yeme - içme amaçlı yeniden işlevlendirilen Durusoy Konutu ve Sipahioğlu Konutu'dur. Bunların yanında işlevi değiştirilmeden restorasyonu yapılmış Gürses Konutu ve Kök Konutu da işlev değişikliğinin etkilerini belirlemek amacıyla diğer örneklerle beraber incelenmiştir.

\section{A. HASANAĞalar KONAĞI (256 ADA 56 PARSEL)- ALANYA KÜLtÜR MÜDÜRLÜĞÜ}

İlk örnek ikinci yerleşim alanında bulunan, günümüzde Belediye tarafından, Kültür Müdürlüğü ofisi olarak kullanılan Hasanağalar Konağı'dır (Şekil 7-8).

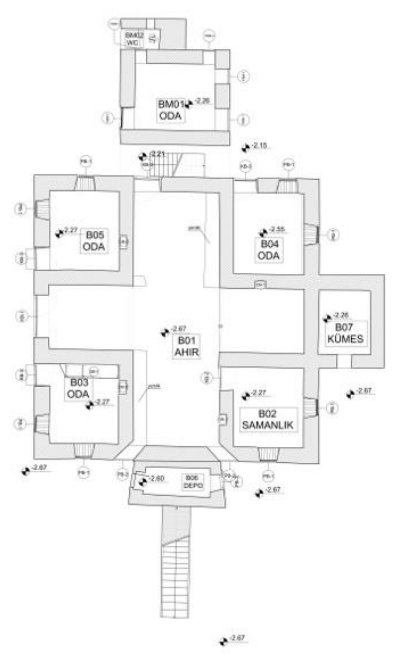

(a)

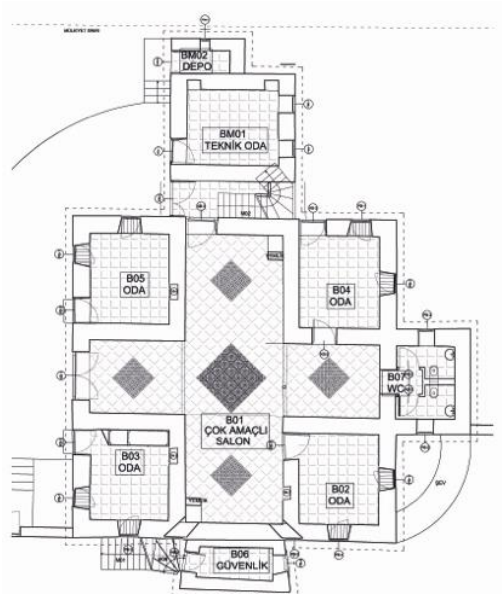

(d)

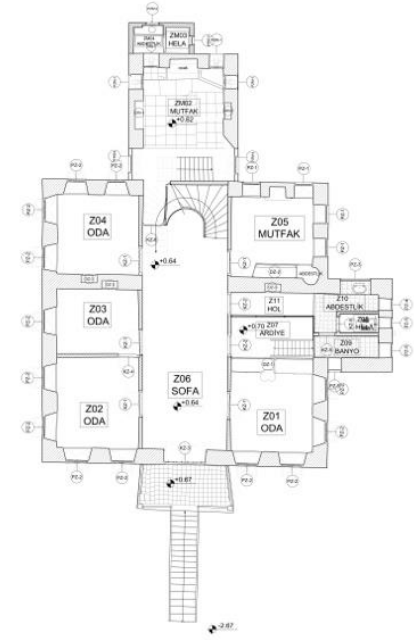

(b)

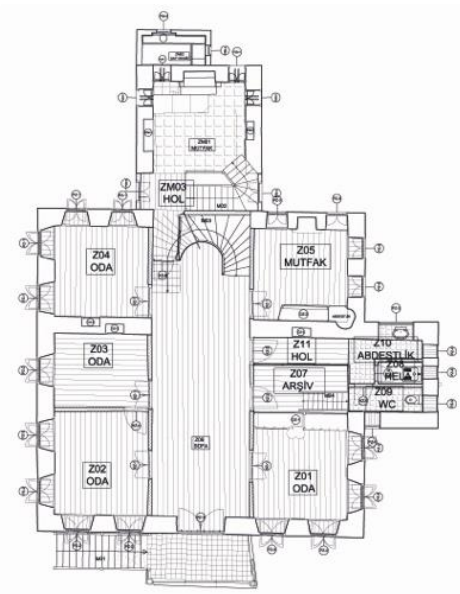

(e)

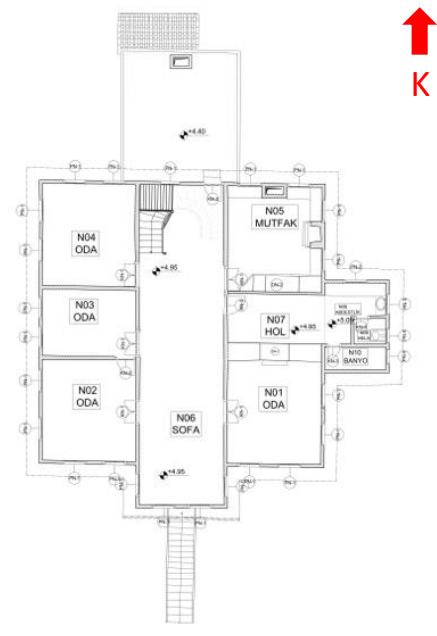

(c)

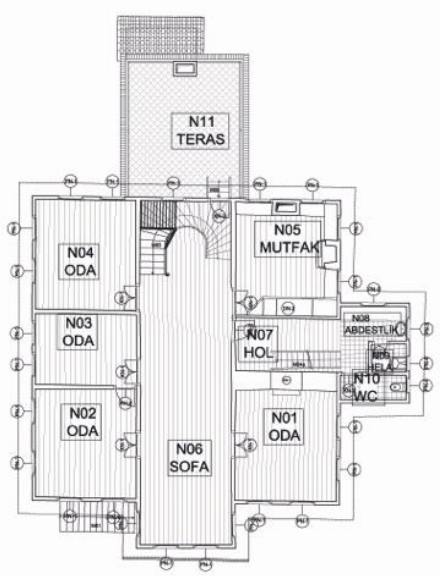

(f) 


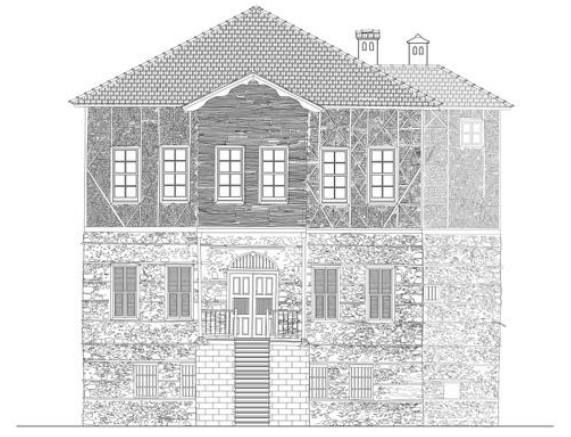

$(g)$

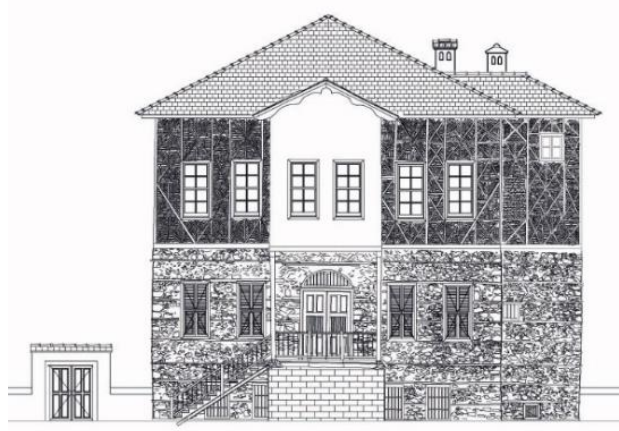

(h)

Şekil 7. Hasanağalar Konağı (a) Restitüsyon-Zemin kat planı, (b) Restitüsyon-1. kat planı, (c) Restitüsyon-2. kat planı, (d) Restorasyon-Zemin kat planı, (e) Restorasyon-1. kat planı, (f) Restorasyon-2. kat planı,

(g) Restitüsyon-Ön cephe, (h) Restorasyon-Ön cephe [13].

Yapının özgün plan şeması, iç sofalı plan tipindedir. Zemin kat, üst katlardan bağımsız bir bölümdür ve iki ana girişi vardır. Bazı mekanlarına da sokağa doğrudan açılan kendi girişleri vardır. Restitüsyon projesinde zemin katta 4 oda, 1 samanlık, 1 kümes, 1 depo ve bu mekanların ortasında kalan alanın ahır olduğu belirtilmiştir. Ancak geleneksel Alanya konut mimarisi göz önünde bulundurulduğunda ahırın $\rightarrow$ avlu, odaların $\rightarrow$ gedey olduğu düşünülmektedir. Arka bahçede bir hela ve tek hacimli ayrık nizamlı bir kütle vardır. Bu kütlenin özgün işlevi ile bir bilgiye ulaşılamamıştır. Birinci ve ikinci katlar konutun aile yaşamının olduğu bölümdür. Birinci kata giriş hem ön hem arka cepheden tek kollu bir merdiven ile sağlanmıştır. Birinci katta sofadaki iki kollu bir merdiven ile ikinci kata ulaşılmaktadır. Restitüsyon projesinde birinci katta 2 adet mutfak, 4 oda, 1 abdestlik, 1 ardiye, 1 hela ve sofa olduğu belirtilmiştir. Aynı katta birbirine çok yakın 2 mutfak olması pek doğru bir değerlendirme gibi gelmemektedir. Geleneksel Türk konutu mimarisi düşünüldüğünde dışarda kalan kütlenin mutfak olma ihtimali daha yüksektir. İkinci kat planında 4 oda, sofa, 1 mutfak, 1 hela ve 1 abdestlik olduğu görülmektedir. $\mathrm{Bu}$ kattaki mutfağında yakın dönemdeki müdahalelerle odadan mutfağa dönüştürüldüğü düşünülmektedir.

Restorasyon çalışmalarında konutun iç duvarları korunmuş ve dolayısıyla iç sofalı plan şeması okunmaktadır. Sadece ana giriş merdiveninin yönü değiştirilmiştir. Koruma projelerine göre zemin katta odalar aynen korunmuştur. Depo $\rightarrow$ güvenlik, kümes $\rightarrow$ wc, ahır $\rightarrow$ çok amaçlı salon, dış mekânda kalan kütle $\rightarrow$ teknik oda, bu kütlenin yanındaki hela $\rightarrow$ depo olarak yeniden işlevlendirilmiştir. Birinci katta mutfak ve odalar yine aynı işlevle değerlendirilmiştir. Ardiye $\rightarrow$ arşiv, hela + abdestlik $\rightarrow$ wc olarak yeniden işlevlendirilmiştir. İkinci katta işlevlerde değişiklik yapılmamıştır. Sadece dış mekanda kalan kütlenin çatısı $\rightarrow$ teras olarak kullanılmıştır.

Yapının bozulan ve yıkılan kısımları, özgün yapım tekniği ve malzeme ile tamamlanmıştır. Zemin ve birinci katlarda ahşap hatıllı moloz taş duvar, ikinci katta ahşap çatkı tuğla dolgu duvar, çıkmada ise ahşap bağdadi duvar tekniği kullanılmıştır. Binanın ilk yapılışı esnasında ekonomik sebeplerden ötürü ikinci katının cephe duvarlarının sıvanamadığı bilinmektedir. Kent sakinleri tarafından bu sıvasız görünüşü ile belleklerde yer ettiği için üst kattaki çıplak tuğla görünümünü korunmuştur. Ancak ahşap bağdadi çıkmanın dış cephesi sıvanmış ve boyanmıştır. 


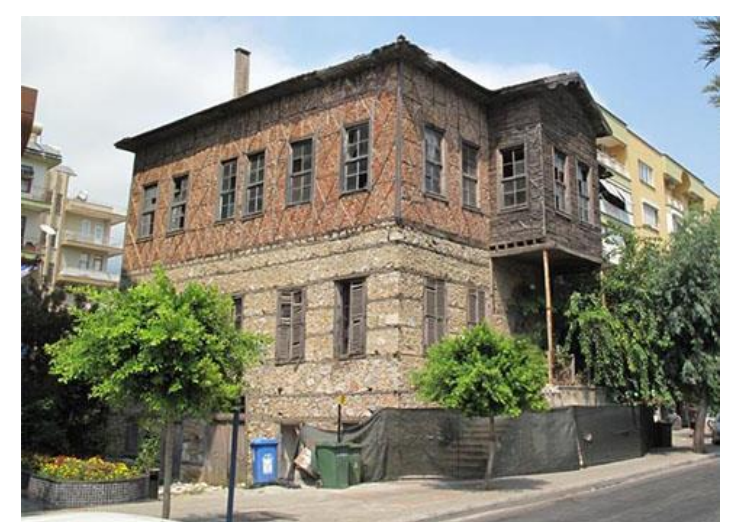

(a)

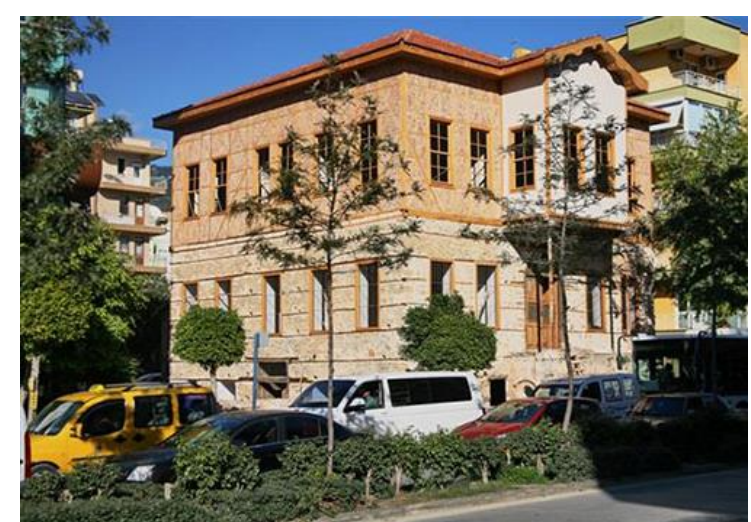

(b)

Şekil 8. Hasană̆alar Konă̆ı (a) Onarım öncesi ve (b) Onarım sonrası.

\section{B. ÇIRPANLI KONUTU (244 ADA- 207 PARSEL)- DERNEK OFISİ}

Ofis olarak işlevlendirilen diğer yapı, ikinci yerleşim alanında bulunan Çırpanlı Konutu'dur. Bu yapı günümüzde dernek ofisi olarak kullanılmaktadır.

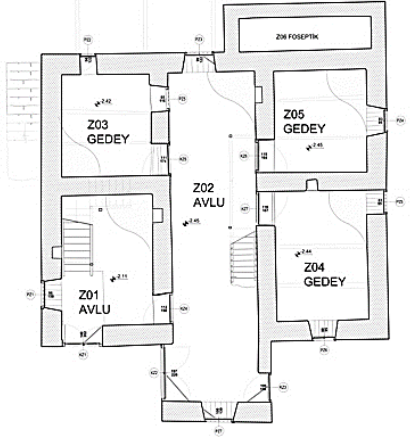

(a)

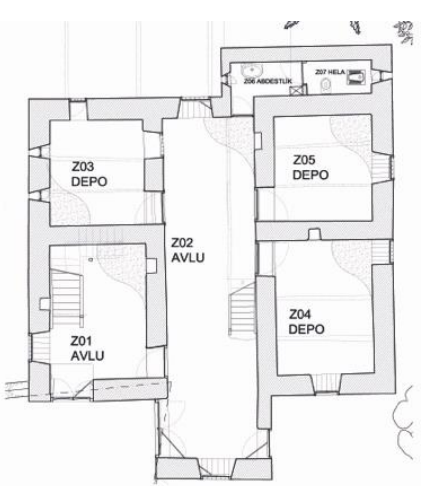

(d)

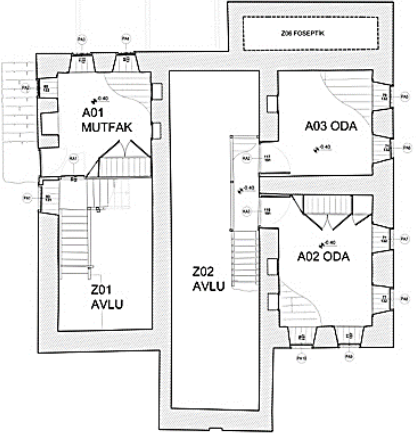

(b)

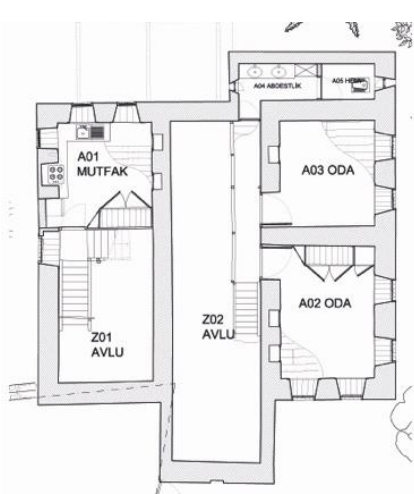

(e)

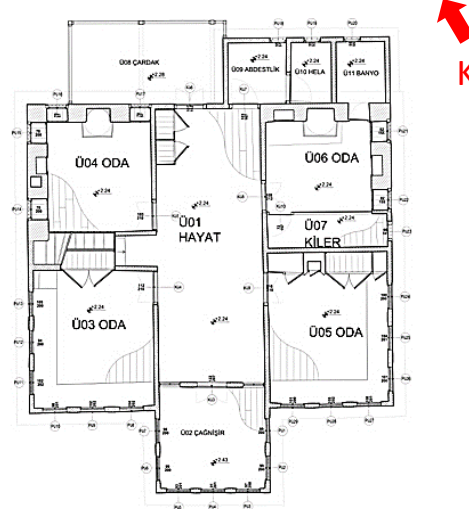

(c)

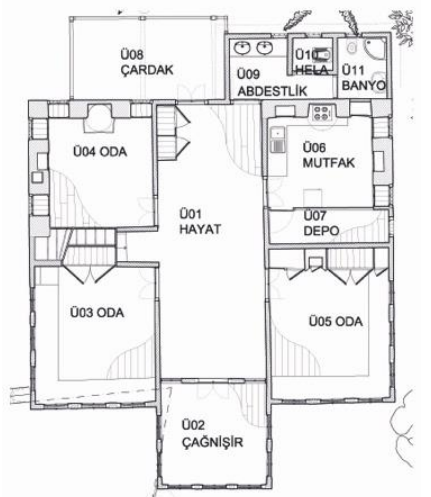

(f) 


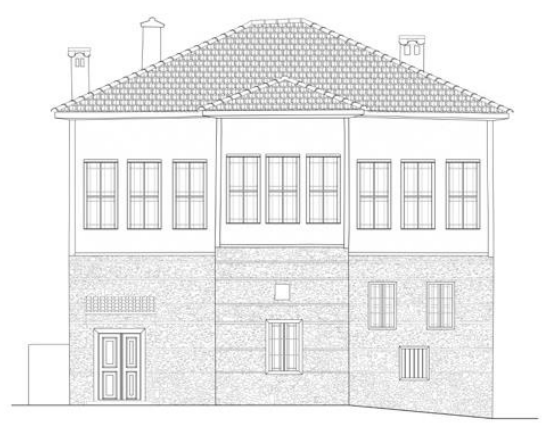

(g)

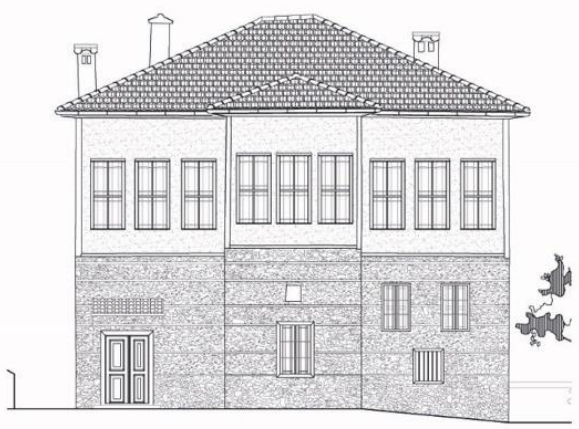

(h)

Şekil 9. Mustafa Çırpanlı Konutu (a) Restitüsyon-Zemin kat planı, (b) Restitüsyon-1. kat planı, (c) Restitüsyon-2. kat planı, (d) Restorasyon-Zemin kat planı, (e) Restorasyon-1. kat planı, (f) Restorasyon-2. kat plani,

(g) Restitüsyon-Ön cephe, (h) Restorasyon-Ön cephe [14].

Yapının özgün plan şeması, iç sofalı plan tipindedir. Zemin kat ve üstündeki iki kattan meydana gelmektedir. Zemin kat, hayvanlar ve depo mekanları içindir. Birinci ve ikinci katlar aile yaşamının geçtiği katlardır. Zemin katta 2 avlu, 3 gedey ve bir hela çukuru vardır. Yapıya önce küçük bir avludan girilir. Bu avludan da büyük bir avluya geçilir. Zemin kattaki tüm mekanlar büyük avluya açılır. Büyük avludaki bir merdiven ile üst kata çıkılır. Küçük avludaki bir merdiven ile de birinci kattaki mutfak mekanına ulaşılır. Birinci katta 2 oda, sofa ve hela çukuru bulunmaktadır. Ayrıca küçük avludan çıkılan mutfak bölümü vardır. Bu avludan sadece mutfağa çıkılması, mutfağın birinci kat kotunda planlanmasına rağmen ailenin yaşam alanından bağımsız olması ilginçtir. İkinci katta 4 oda, hayat, çağnişir, çardak, abdestlik ve hela bölümleri vardır. Restorasyon çalışmalarında konutun plan şeması büyük ölçüde korunmuştur. En önemli değişiklik arka cephede zemin ve birinci katlara wc kütlelerinin eklenmesi ile ikinci kattaki bir odanın mutfağa dönüştürülmesidir.

Restorasyon öncesinde yapının tüm cephesinin sıvalı ve boyalıdır. Sıva ve boyasının niteliğinden, yapının özgün mimarisine özgü olmadığı ve günümüze yakın bir dönemde yapılmış olduğu anlaşılmaktadır. Restorasyon uygulamaları sırasında söz konusu sıva ve boylar sökülmüş, yapının özgün cephesi ortaya çıkarılmıştır.

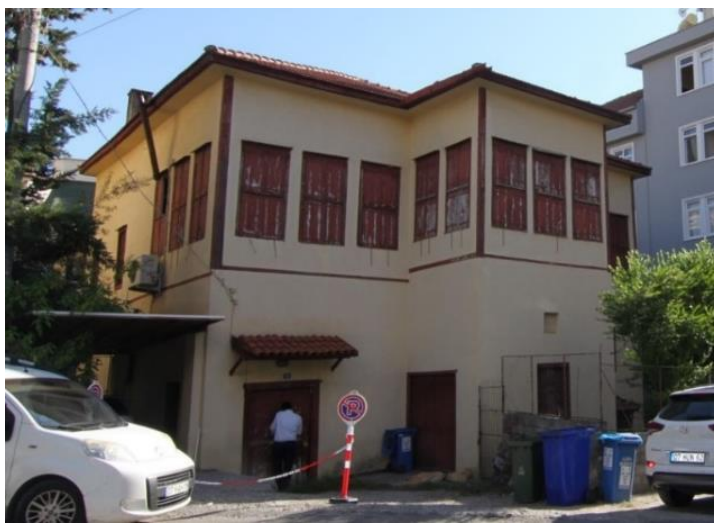

(a)

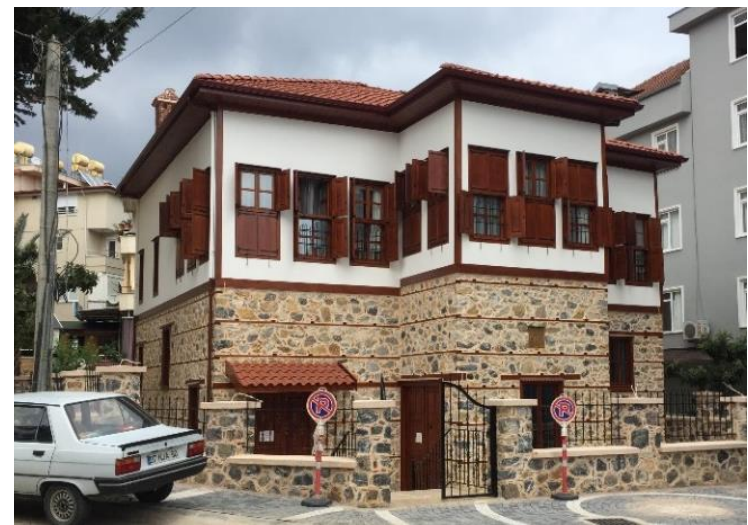

(b)

Şekil 10. Mustafa Çırpanlı Konutu (a) Onarım öncesi ve (b) Onarım sonrası.

\section{SEZER KONUTU (401 ADA-1 PARSEL)- CENTAUERA BUTIK OTEL}

Konaklama amaçlı yeniden işlevlendirilen örneklerden birincisi birinci yerleşim alanında bulunan Tophane mahallesindeki Centauera Butik Otel'dir (Şekil 11-12). 


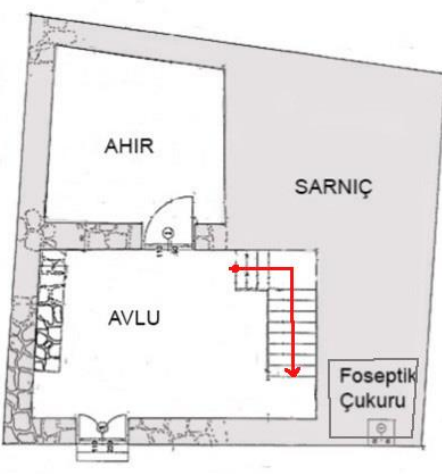

(a)

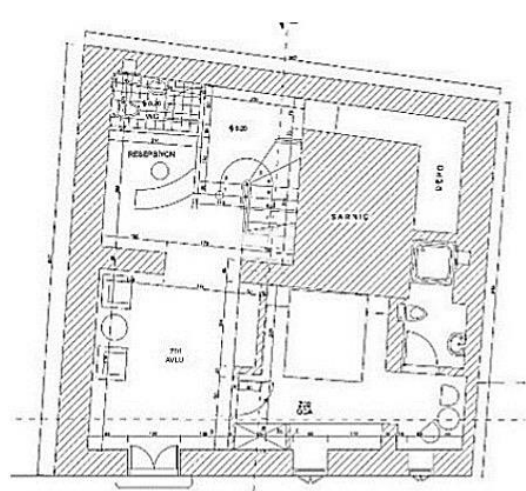

(d)

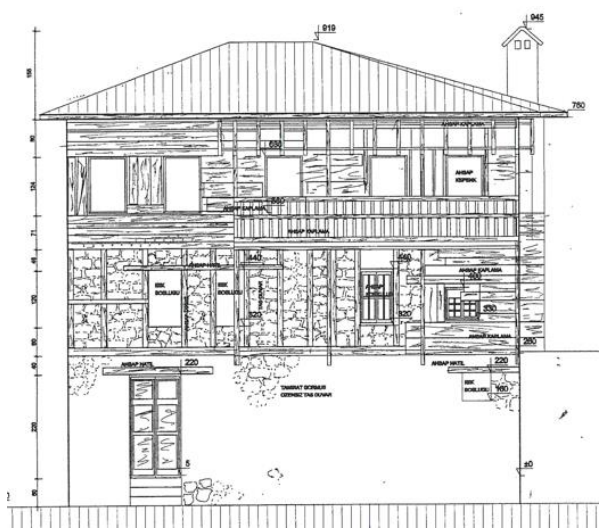

(g)

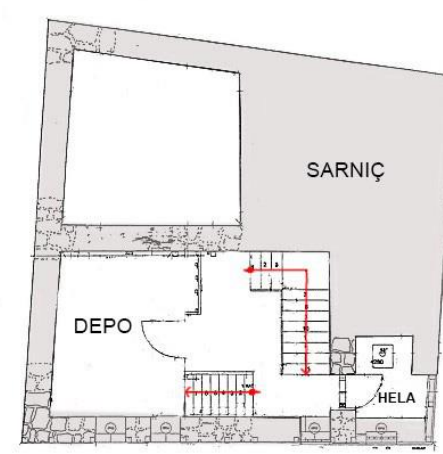

(b)

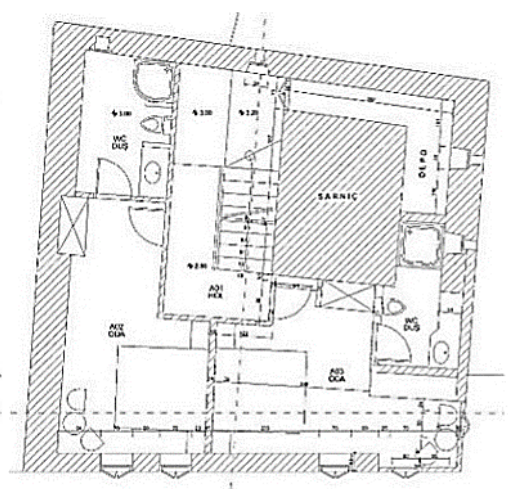

(e)

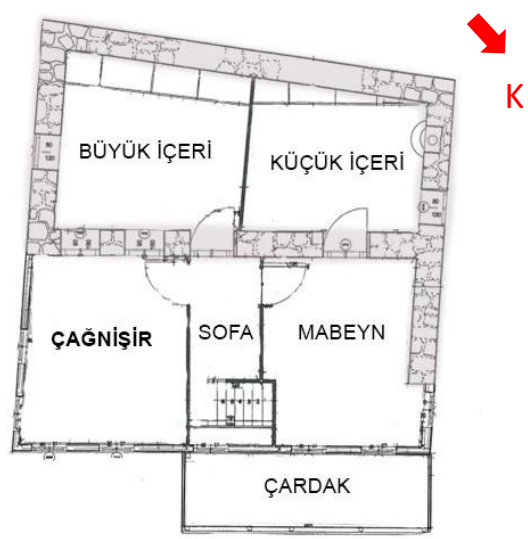

(c)

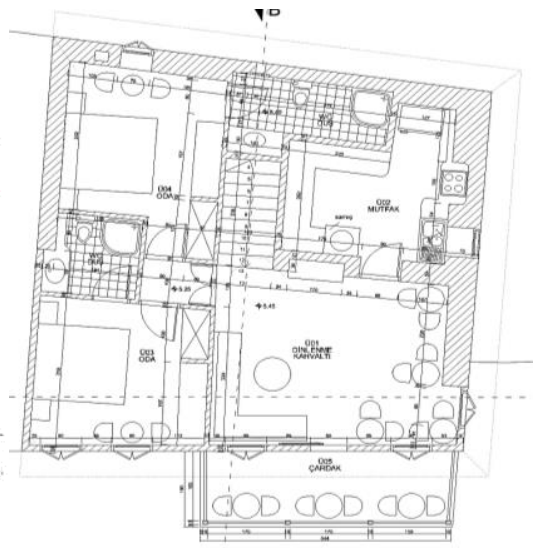

$(f)$

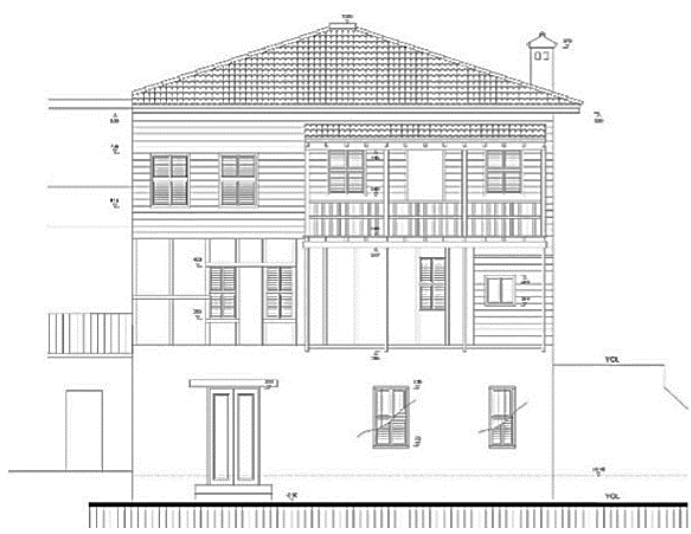

(h)

Şekil 11. Sezer Konutu (a) Restitüsyon-Zemin kat planı, (b) Restitüsyon-1. kat planı, (c) Restitüsyon-2. kat planı, (d) Restorasyon-Zemin kat planı, (e) Restorasyon-1. kat plant, (f) Restorasyon-2. kat planı,

(g) Restitüsyon-Ön cephe, (h) Restorasyon-Ön cephe [15].

Yapının özgün plan şeması, dış sofalı plan tipindedir. Zemin kat ile üstündeki iki kattan meydana gelmektedir. Özgün planında zemin katta yapının girişinin olduğu avlu, ahır ve büyük bir sarnıç bulunmaktadır. Avludaki L planlı bir merdiven ile birinci kata ulaşılmaktadır. Birinci katta bir depo ve hela mekânı bulunmaktadır. Birinci kattan tek kollu bir merdiven ile ikinci kata çıkılmaktadır. İkinci katta büyük içeri, küçük içeri, mabeyn, sofa ve çağnişir mekanları yer almaktadır.

Otel olarak işlevlendirilen halinde konutun özgün plan şeması tamamen bozulmuştur. Giriş kattaki ahırın iç duvarları yıkılmış, bu mekâna resepsiyon, wc ve U planlı bir merdiven konulmuştur. Özgün 
merdiven kaldırılmış ve hela çukuru ile birleştirilmiş, ikisinin kapladığı alana banyolu bir oda yapılmış̧ır. İkinci kattaki tüm iç duvarlar kaldırılmış, özgün plandaki sofa, depo ve hela mekanlarının kapladığı tüm alan banyolu iki oda haline getirilmiştir. Üçüncü kattaki tüm iç duvarlar kaldırılmış, özgün plandaki 2 oda, mabeyn ve çağnişirin kapladığı tüm alana mutfak, 2 adet banyolu oda, 1 oturma salonu yerleştirilmiştir. Ayrıca oturma salonunun giriş cephesine bakan kısmına bir teras çıkması eklenmiştir.

Alt katlarda ahşap hatıllı moloz taş kullanımı, manzaraya bakan üst katta ahşap bağdadi duvar tekniği uygulaması ile strüktür ve malzemede özgünlüğe saygı duyulmuştur. Ancak iç duvarların kaldırılması müdahaleleri ile, konutun özgün plan şemasının tamamen kaybedilmesine ve özgün strüktür malzemeden büyük ölçüde kayıplara neden olunduğu açıkça görülmektedir. Yapının otel işlevli plan şemasında artık dış sofalı plan tipini okumak mümkün değildir. Yapının cepheleri de yepyeni bir görünüm kazanmakla birlikte malzeme ve teknik açıdan özgün haline uyarlanmıştır.

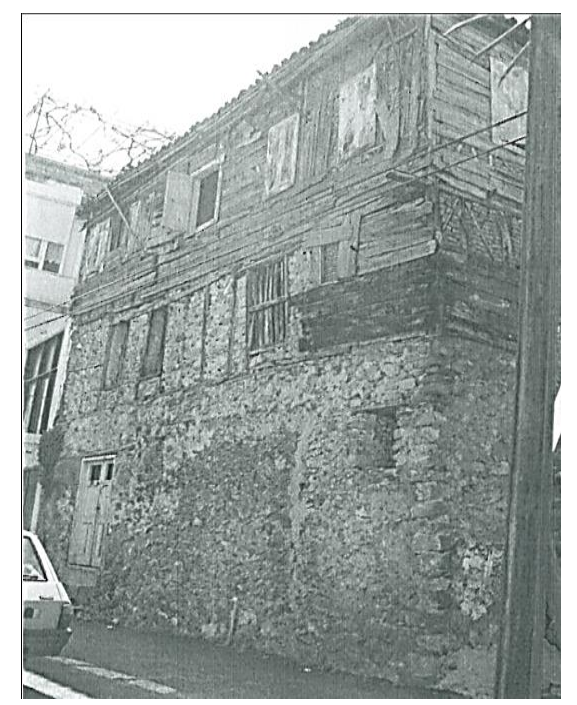

(a)

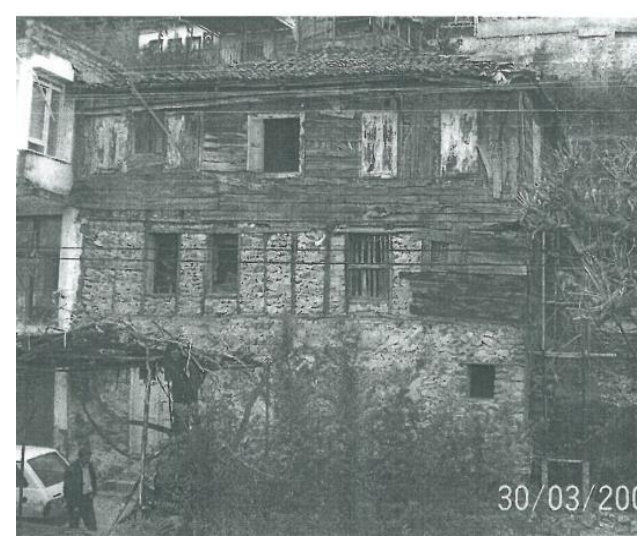

(c)

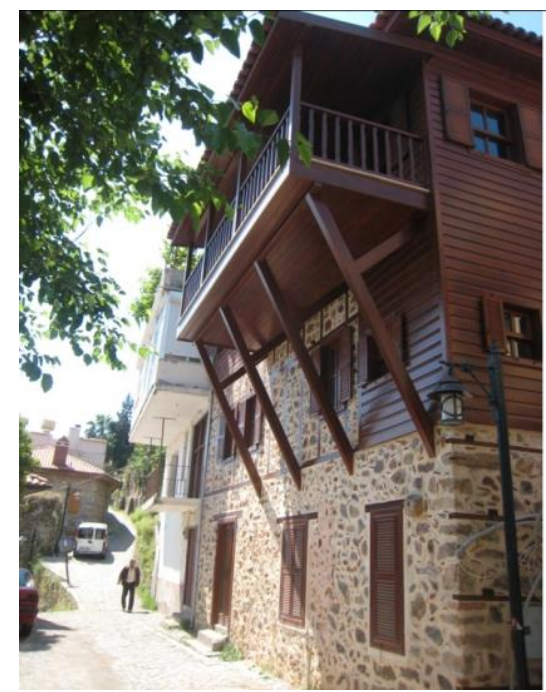

(b)

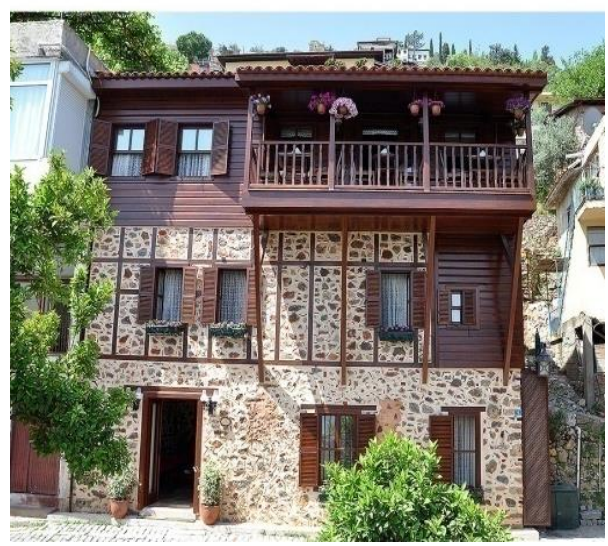

(d)

Şekil 12. Sezer Konutu (a) Onarım öncesi yan cephe, (b) Onarım sonrast yan cephe, (c) Onarım öncesi ön cephe, (d) Onartm sonrast ön cephe.

\section{D. ŞİMŞEK KONUTU (406 ADA- 9 PARSEL)- VİLLA TURCA BUTİK OTEL}

Birinci yerleşim alanındaki Tophane mahallesinden bir diğer örnek ise Villa Turca Butik Otel'dir (Şekil 13-14). 


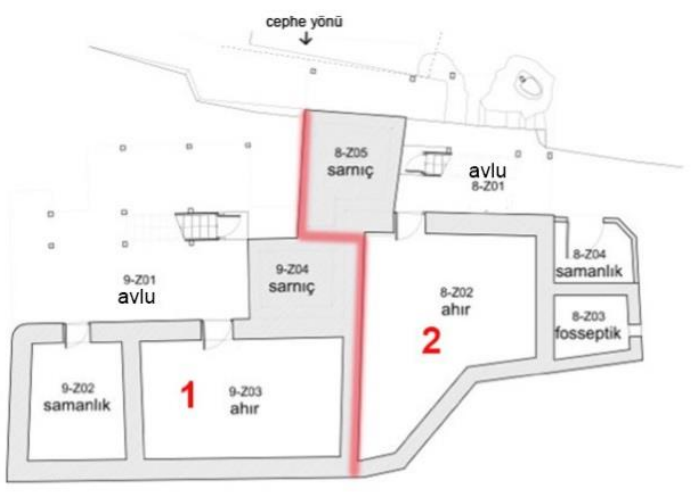

(a)

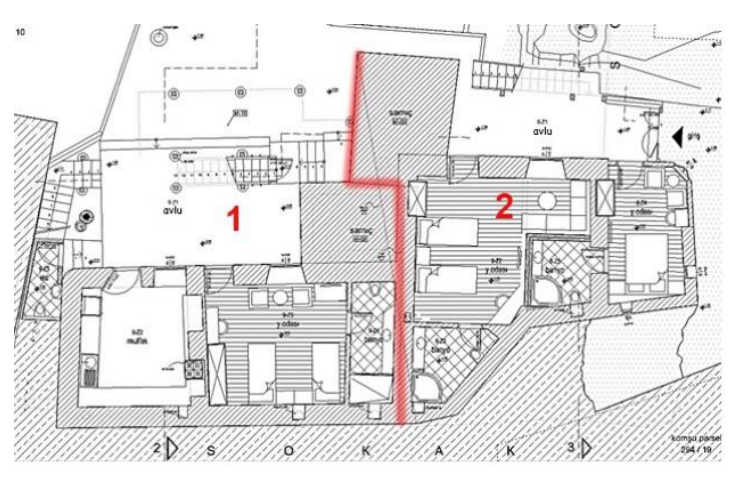

(b)

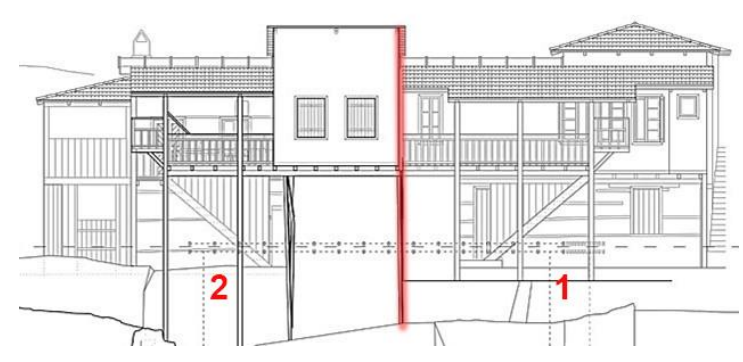

(e)

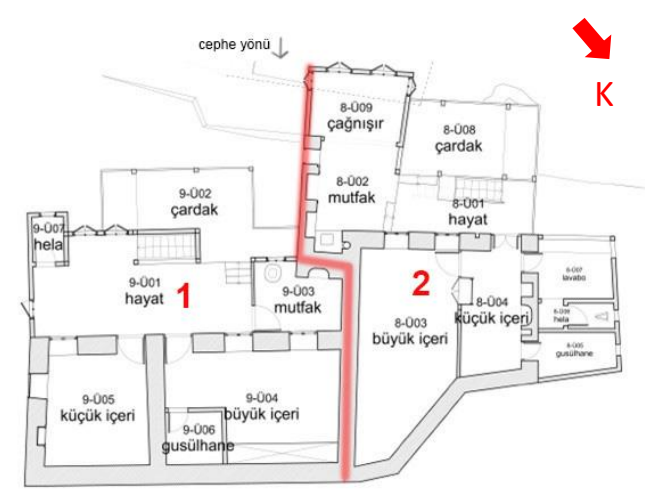

(b)

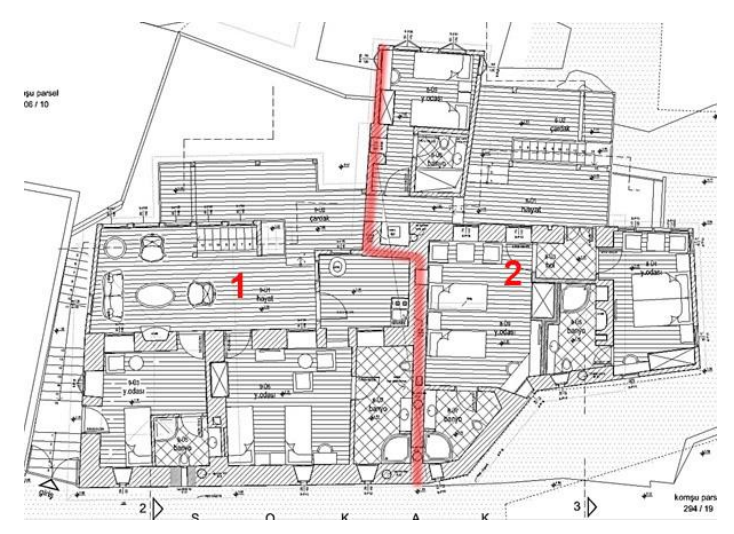

(d)

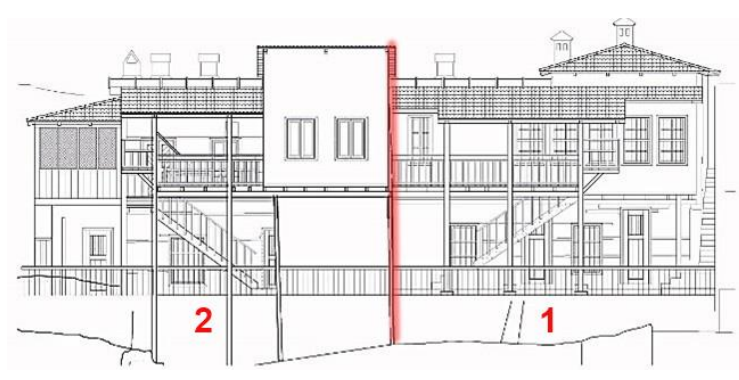

(f)

Şekil 13. Şimşek Konutu (a) Restitüsyon-Zemin kat planı, (b) Restitüsyon-1. kat planı, (c) Restorasyon-Zemin kat plant, (d) Restorasyon-1. kat planı, (e) Restitüsyon-Ön cephe, $(\boldsymbol{f})$ Restorasyon-Ön cephe [15].

Yapının özgün plan şeması, dış sofalı plan tipindedir. Zemin kat ile üstündeki bir kattan meydana gelmektedir. Yapı bölge de birkaç örneği daha bulunan birleşik ev şeklinde iki adet dış sofalı konutun bitişik nizam inşa edilmesiyle oluşturulmuştur. Çizimlerdeki kırmızı hat, iki evin arakesitidir. Her iki evin özgün planında zemin katta bir avlu, bir sarnıç, bir ahır, 1 samanlık ve 1 fosseptik bölümü vardır. Üst katlarda ise hayat, çardak, mutfak, büyük içeri, küçük içeri, gusülhane, wc mekanları vardır. Sadece evlerden birisinde diğerinden farklı olarak çağnişir mekânı vardır.

Konutun otele dönüştürülmüş halinde 1 numaralı konutun zemin katındaki avlu ve sarnıç aynen korunmuştur. Ahır $\rightarrow$ banyolu odaya; samanlık $\rightarrow$ mutfak mekanına dönüştürülmüştür. Dönüşümde plan şeması korunmuştur. 2 numaralı konutun zemin katındaki avlu ve sarnıç korunmuştur. Ahır $\rightarrow$ banyolu odaya, samanlık ve fosseptik birleştirilerek $\rightarrow$ banyolu odaya, küçük içeri $\rightarrow$ yatak holü + banyoya dönüştürülmüştür. Dönüşüm sırasında plan şeması korunmamıştır. 1 numaralı konutun üst 
katındaki küçük içeri $\rightarrow$ banyolu tek kişilik odaya, büyük içeri $\rightarrow$ banyolu iki kişilik odaya dönüştürülmüştür. Büyük içerideki gusülhane tamamen kaldırılmıştır. Mutfak mekânı korunmuş ancak içindeki özgün ocak kaldırılmıştır. Cepheye yansıyan wc kütlesi de tamamen kaldırılmıştır. Çardak ve hayat mekanları korunmuştur. Dönüşümde plan şeması kısmen korunmuş, özgün iç duvarlardan yıkım yapılmamıştır. Buna karşılık banyo mekânı eklemeleri ve yapı elemanlarından kayıplar olmuştur. 2 numaralı konutun üst katındaki büyük içeri $\rightarrow$ banyolu odaya, çağnişir + mutfak $\rightarrow$ banyolu odaya, lavabo $+\mathrm{wc}+$ gusülhane $\rightarrow$ odaya, küçük içeri $\rightarrow$ banyo + yatak holüne dönüştürülmüsstür. Çardak ve hayat mekanları korunmuştur. Özgün plan şeması bozulmuştur.

Yapının büyük bir kısmı yıkılmış, yıkılan kısımlar geleneksel yapım teknikleri ve malzeme ile tamamlanmıştır. Cephede kullanılan malzeme ve teknik özgün mimariyi yansıtsa da yeni işlev için tasarlanan ekler ve bu eklerin cepheye yansıması sonucu yapıda bölgeye özgü cephesel özellikler görülememiştir.

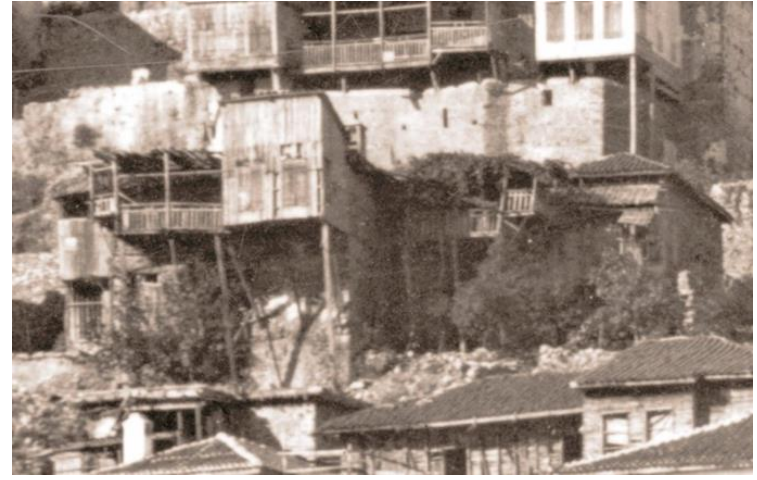

(a)

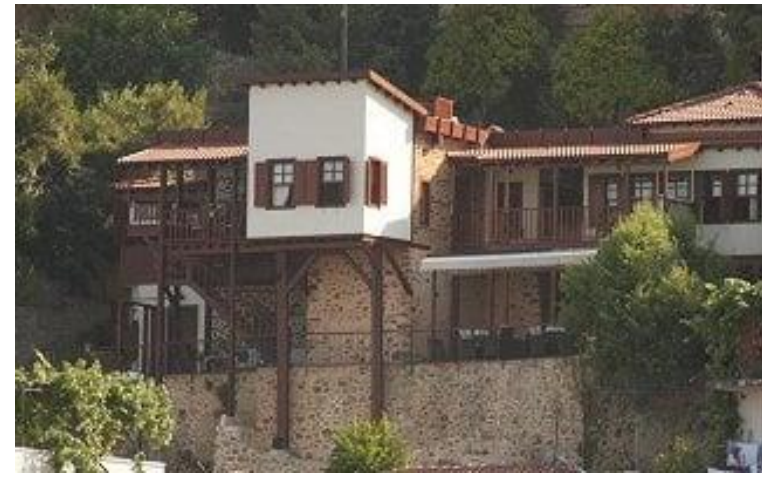

(b)

Şekil 14. Sezer Konutu (a) Onarım öncesi ön cephe, (b) Onarım sonrası ön cephe.

\section{E. DURUSOY KONUTU (263 ADA- 5 PARSEL)- BİSTRO FLOYD CAFE}

Kafe/restoran işlevi verilen yapılardan birincisi, ilk yerleşim alanı ile ikinci yerleşim alanı arasında yer alan Durusoy Konutu'dur. Günümüzde Bistro Floyd ismiyle hizmet vermektedir (Şekil 15-16).

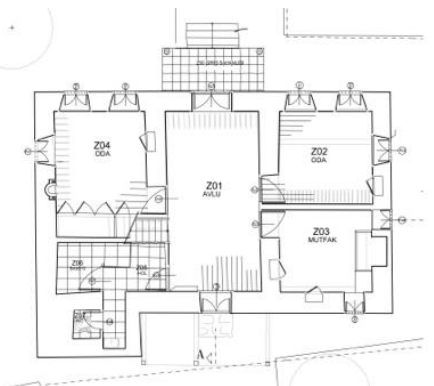

(a)

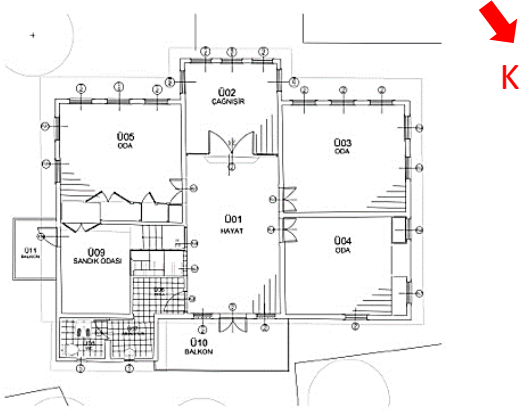

(b) 


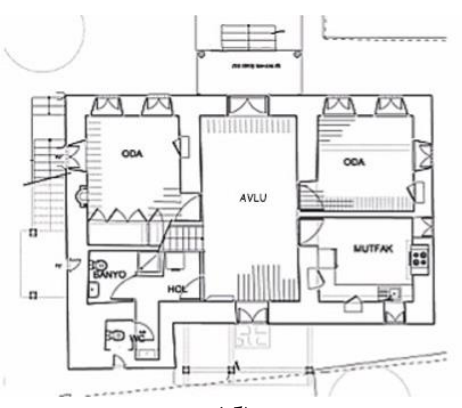

(d)

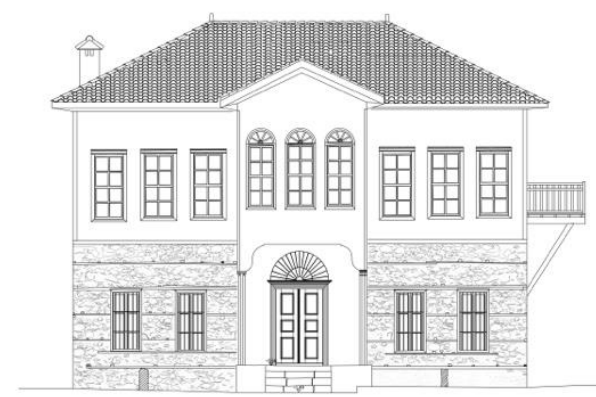

(g)

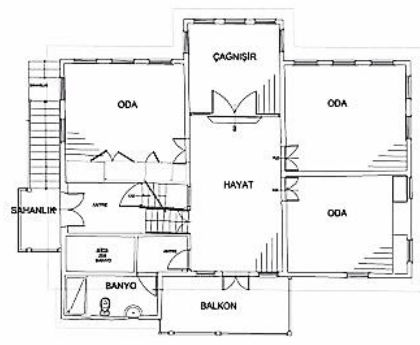

(e)

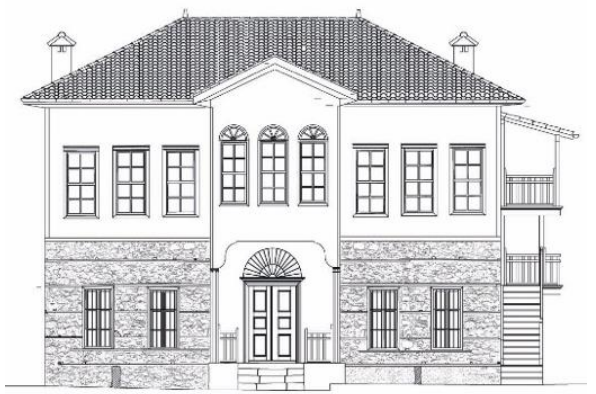

(h)

Şekil 15. Durusoy Konutu (a) Restitüsyon-Zemin kat planı, (b) Restitüsyon-1. kat planı, (c) Restorasyon-Zemin kat planı, (d) Restorasyon-1. kat planl, (e) Restitüsyon-Ön cephe, $(f)$ Restorasyon-Ön cephe [14].

Yapının özgün plan şeması, iç sofalı plan tipindedir. Zemin kat ile üstündeki bir kattan meydana gelmektedir. Özgün planında zemin katta yapının girişinin olduğu avlu, mutfak, 2 oda ve wc bulunmaktadır. Üst katta 3 oda, sofa, sofanın bir kenarında çağnişir diğer ucunda çardak, 1 banyo ve merdivenle sahanlığında farklı kotta düzenlenmiş bir sandık odası bulunmaktadır.

Konutun kafeye dönüştürülmüş halinde giriş kat düzeni aynen korunmuştur. Üst kat plan şeması da büyük ölçüde korunmuştur. Yalnız üst kata yan cepheden ayrı bir merdiven ile giriş verilmiş, sandık odası $\rightarrow$ giriş holü haline getirilmiştir. Böylece alt ve üst kat birbirinden bağımsız olarak kullanılabilir hale getirilmiştir.

Yapım tekniği ve malzeme kullanımında yörenin özgün malzemeleri ve tekniği tercih edilerek mevsimsel ayrım gözetilmiştir.

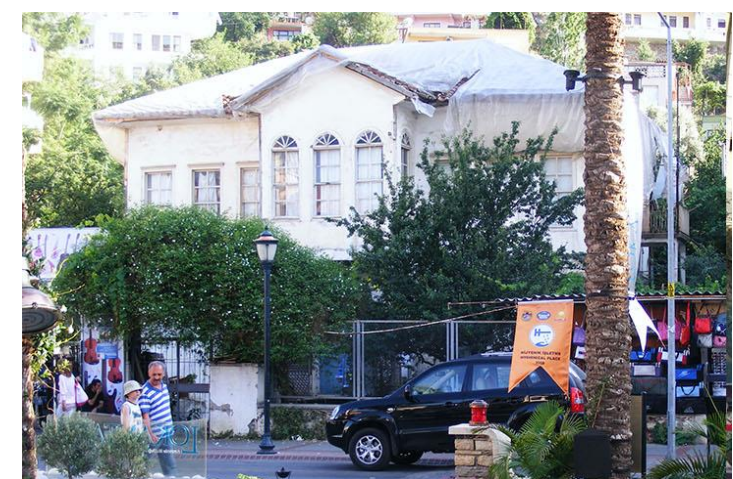

(a)

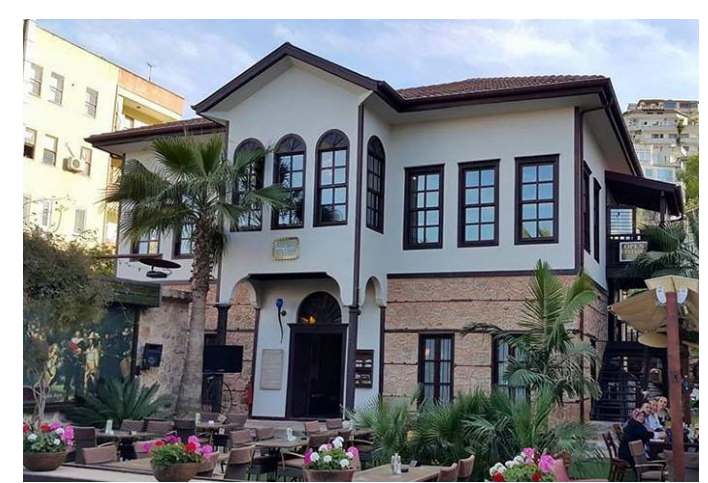

(b)

Şekil 16. Durusoy Konutu (a) Onarım öncesi, (b) Onarım sonrast. 


\section{F. SIPAHIOOĞLU KONUTU (308 ADA- 1 PARSEL)- GARDENIA RESTORAN}

Restoran işlevi verilen diğer örnek, ilk yerleşim alanında yer alan ve Sipahioğlu Konutu'dur. Günümüzde Gardenia Restoran ismiyle hizmet vermektedir (Şekil 17-18).

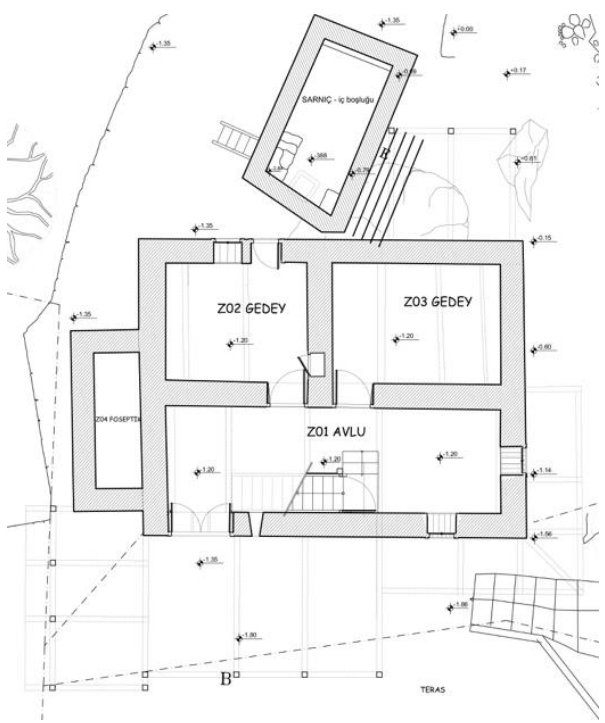

(a)

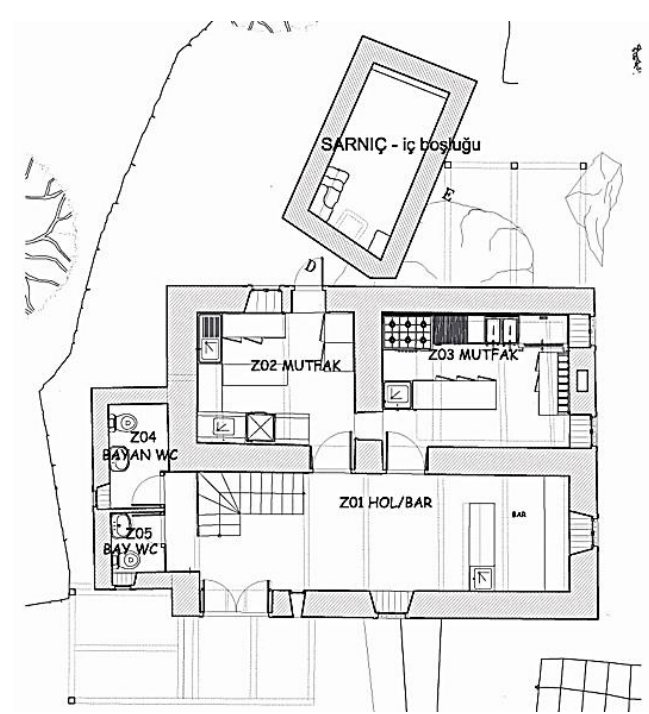

(c)

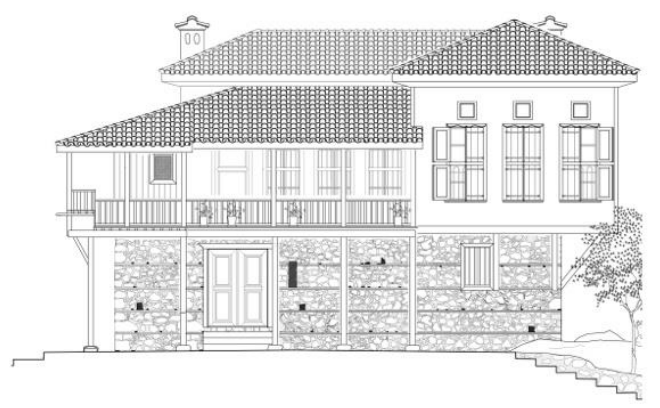

(e)

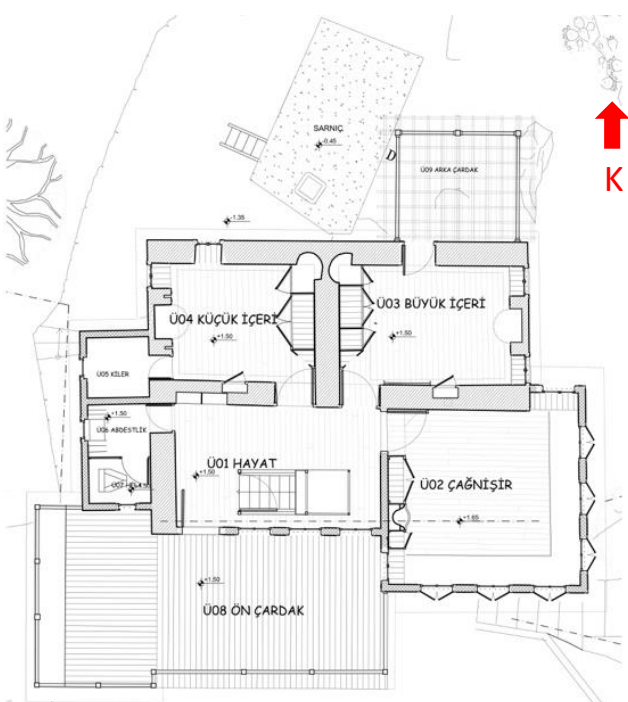

(b)

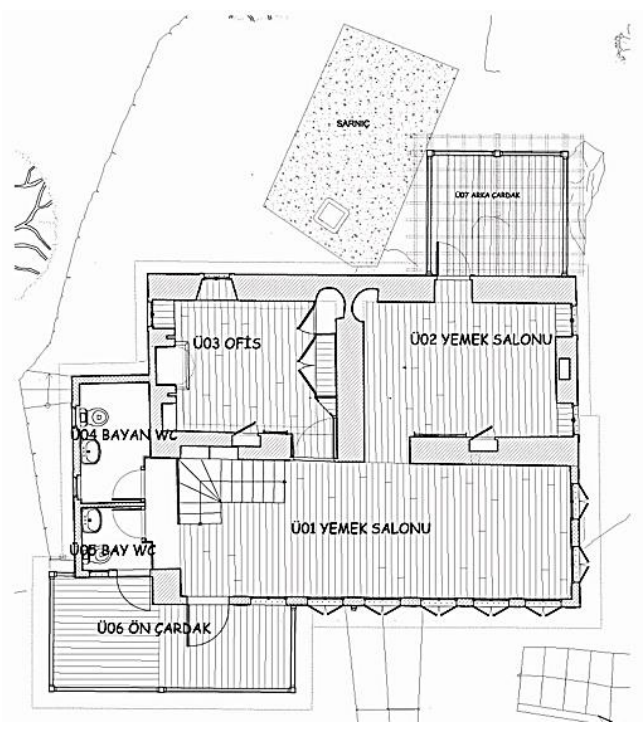

(d)

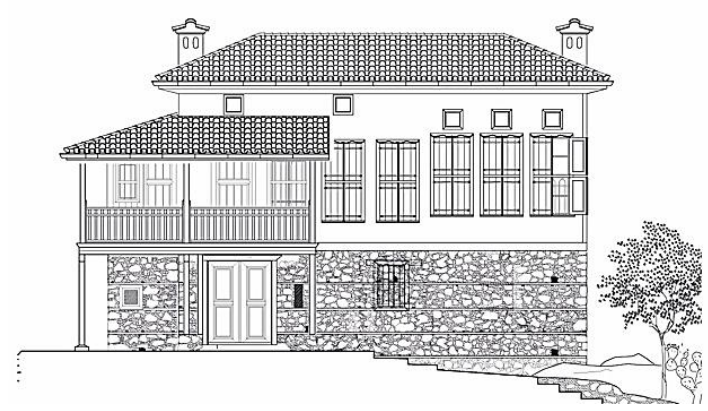

$(f)$

Şekil 17. Sipahioğlu Konutu (a) Restitüsyon-Zemin kat planı, (b) Restitüsyon-1. kat planı, (c) Restorasyon-Zemin kat plani, (d) Restorasyon-1. kat plant,

(e) Restitüsyon-Ön cephe, $(\boldsymbol{f})$ Restorasyon-Ön cephe [14]. 
Yapının özgün plan şeması, dış sofalı plan tipindedir. Zemin kat ile üstündeki bir kattan meydana gelmektedir. Özgün planında zemin katta yapının girişinin olduğu avlu ve 2 gedey bulunmaktadır. Ayrıca yapıya yan cepheden bitişik bir fosseptik ve yapıdan ayrık nizamda bir sarnıç vardır. Üst katta büyük içeri ve buraya bağlı küçük bir çardak, küçük içeri ve buraya bağlı bir kiler, sofa (hayat) ve buraya bağlı çağnişir, büyük bir çardak, hela ve abdestlik mekanları vardır.

Restoran olarak işlevlendirilmiş halinde gedeyler $\rightarrow$ mutfak, avlu $\rightarrow$ bar, fosseptik $\rightarrow$ wc mekanlarına dönüştürülmüştür. İç duvarlarda yıkım ve ekleme yapılmamış, dolayısıyla zemin kat plan şeması korunmuştur. Sarnıca da hiç müdahale edilmemiştir. Üst katta küçük içeri $\rightarrow$ ofise dönüştürülmüş ve kiler mekânı ile arasındaki kapı boşluğu kapatılmıştır. Kiler $\rightarrow$ bayan wc haline dönüştürülmüştür. Büyük içeri ve sofa $\rightarrow$ yemek salonuna dönüştürülmüş, sofanın çağnişir bölümü kaldırılmış, sofaya bağlı çardak küçültülmüsşür. Sonuç olarak üst kat planında her ne kadar dış sofalı plan tipi halen okunabilse de mekanların büyüklükleri ve bağlantıları çok fazla değiştirilmiştir.

Yapım tekniği ve malzeme açısından geleneksel doku ile devamlılık sağlanmaya çalış1lsa da yeni işlevin gerekleri için planda yapılan zorlama müdahaleler cepheye yansıyarak yapıyı geleneksel konut görünümünden uzaklaştırmıştır.

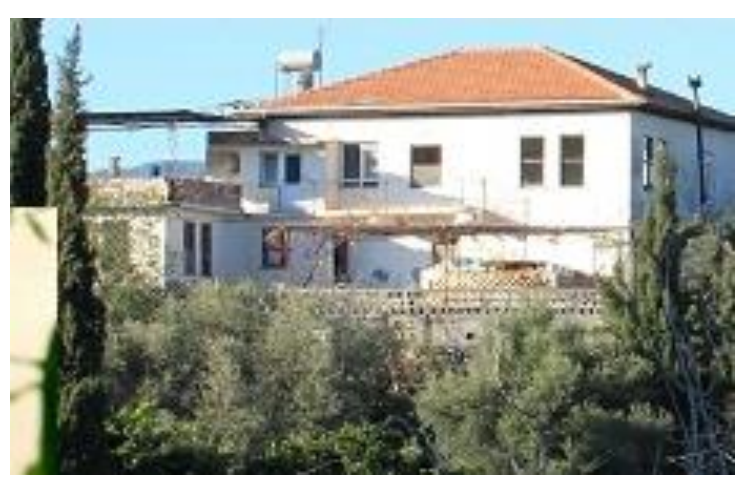

(a)

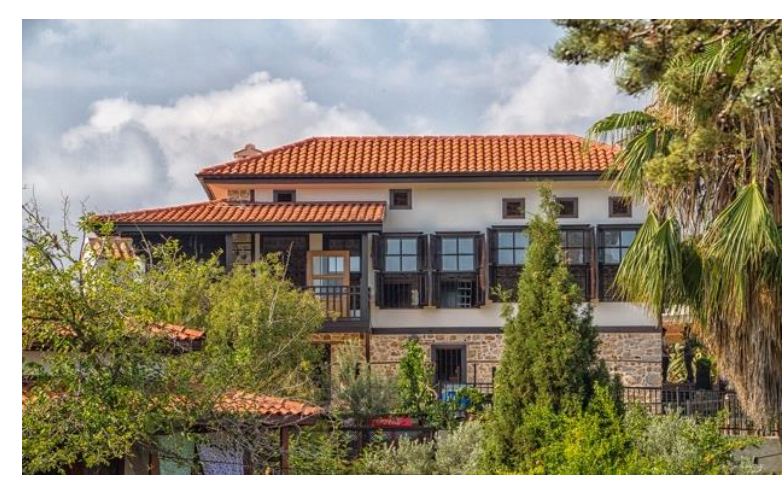

(b)

Şekil 18. Sipahioğlu Konutu (a) Onarım öncesi, (b) Onarım sonrası.

\section{G. ALİ GÜRSES KONUTU (403 ADA- 2 PARSEL)}

İşlev değişikliğinin geleneksel konutlar üzerindeki etkisini daha iyi anlamak için, yine konut olarak kullanımının devam ettirilmesi hedeflenen restorasyon uygulamalarından iki örnek seçilmiştir.

Bu örneklerden birincisi birinci yerleşim alanında yer alan Ali Gürses Konutu'dur (Şekil 19-20). Ali Gürses Konutu, bulunduğu birinci yerleşim bölgesindeki konutların çoğunda olduğu gibi dış sofalı plan şemasına sahiptir. Zemin katta diğer konutlardan farklı olarak iki adet avlu vardır. Birinci avlu diğerine göre daha küçüktür, evin girişi bu avludan sağlanmaktadır, sadece bir oda ve ikinci avluyla bağlantısı vardır. İkinci avlu oldukça büyüktür. Avluda üst kat ile bağlantıyı sağlayan tek kollu bir merdiven bulunur. İki gedey, bu avluya açılır. Ayrıca yapının yan cephesinde bitişik nizam bir sarnıç ile bir fosseptik bulunmaktadır. Üst katta sofa (hayat), mabeyn, büyük içeri, küçük içeri, çağnişir ve bir oda bulunmaktadır. Bu odanın içinde yine oda gibi ayrı bir kapalı mekân bölümü daha vardır. Hayat bölümünde bir hela ve çardak bulunmaktadır. Çardağa, dış mekândan tek kollu bir merdiven ile de çıkılmaktadır.

Özgün işlevi ile restorasyonu yapılan bu yapıda göze çarpan en önemli müdahale odaya dönüştürülen tüm mekanlara, banyo eklenmesidir. Zemin kattaki gedeyler $\rightarrow$ yatak odasına dönüştürülmüştür. Büyük gedeyin içine banyo mekânı eklenirken, hela çukuru $\rightarrow$ küçük gedeyin banyosu haline getirilmiştir. Büyük avlunun bir bölümü $\rightarrow$ çamaşır odası yapılmıştır. Üst katta büyük içeri $\rightarrow$ yatak odasına, sarnıcın içindeki odanın bir bölümü $\rightarrow$ yatak odasının banyosuna dönüştürülmüştür. Sarnıcın içindeki odanın kalan bölümü $\rightarrow$ kiler haline getirilmiştir. Sarnıcın üstündeki oda $\rightarrow$ mutfak mekanına 
dönüştürülmüştür. Mutfaktan kilere bir kapı açılmıştır. Mutfak mekanının doğu cephesinde iki adet pencere açılmıştır. Büyük içeri $\rightarrow$ yatak odasına dönüştürülmüş, içine de banyo eklenmiştir. Mabeyn, çağnişir, hayat, hela ve çardak korunmuştur. Yapım tekniği ve malzemesi ile cephe özellikleri bakımından Ali Gürses Konutu, restorasyon sonrasında da Alanya'nın geleneksel konut mimarisini yansitmaktadir.

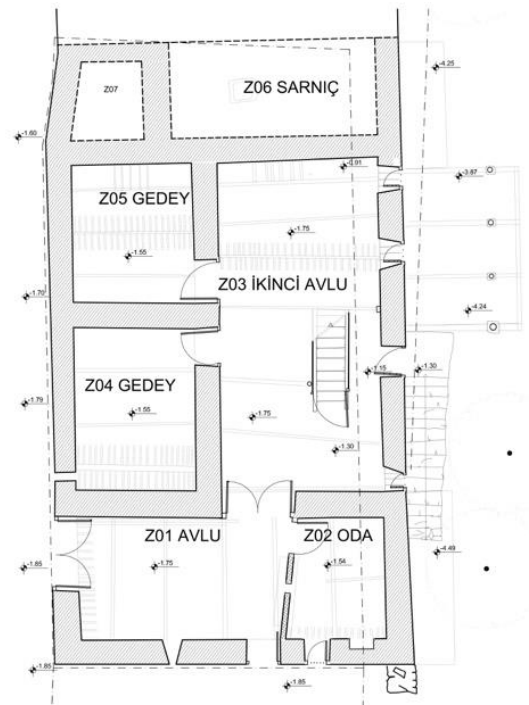

(a)

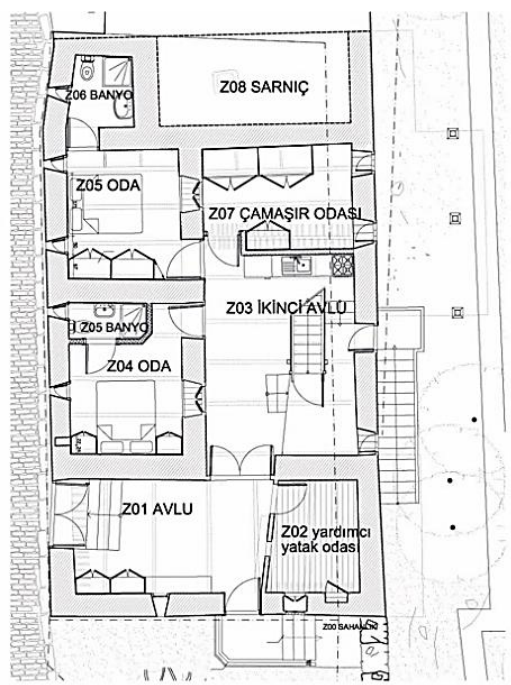

(b)

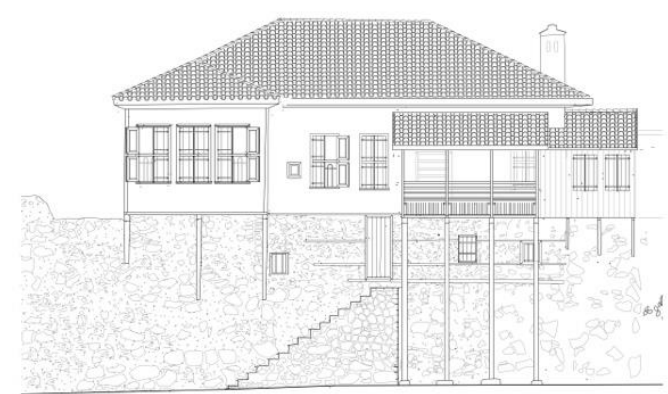

(e)

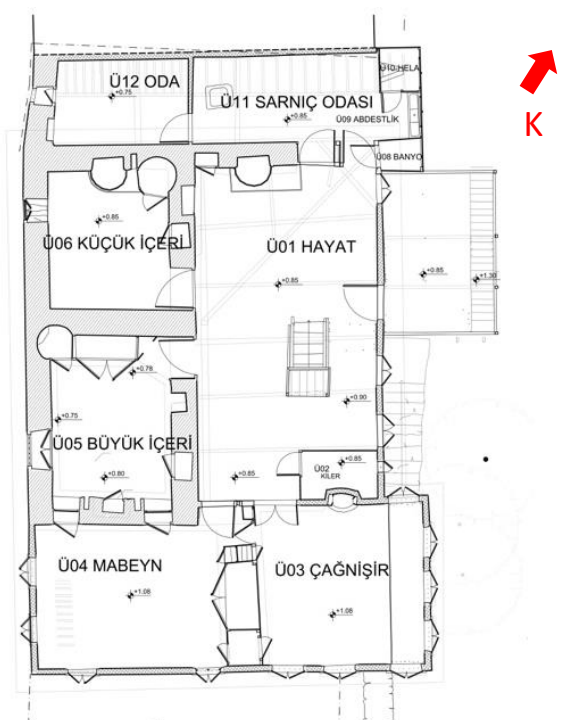

(b)

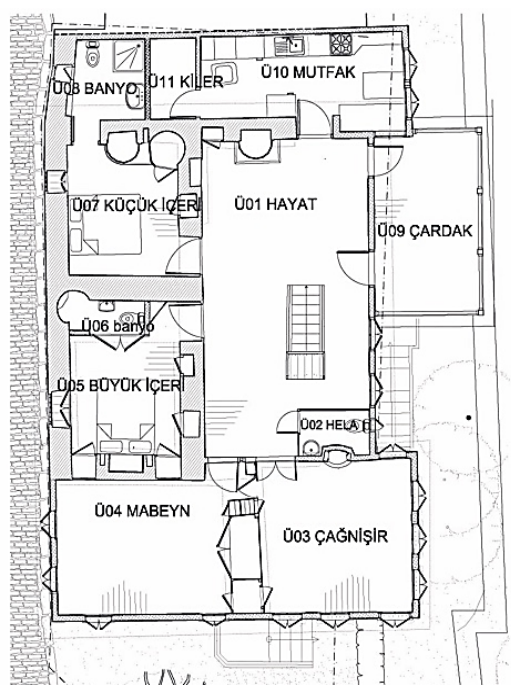

(d)

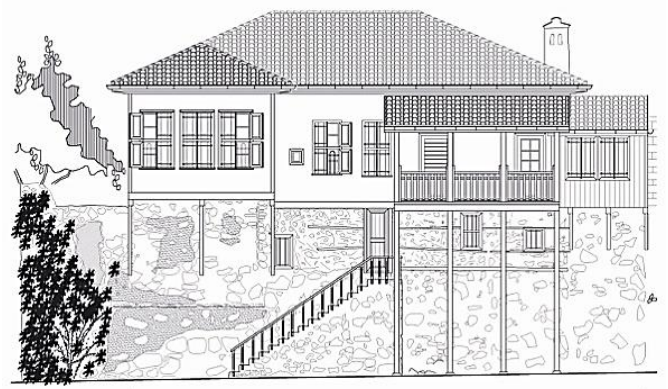

(f)

Şekil 19. Ali Gürses Konutu (a) Restitüsyon-Zemin kat planı, (b) Restitüsyon-1. kat planı, (c) Restorasyon-Zemin kat plani, (d) Restorasyon-1. kat plant,

(e) Restitüsyon-Ön cephe, $(\boldsymbol{f})$ Restorasyon-Ön cephe [14]. 


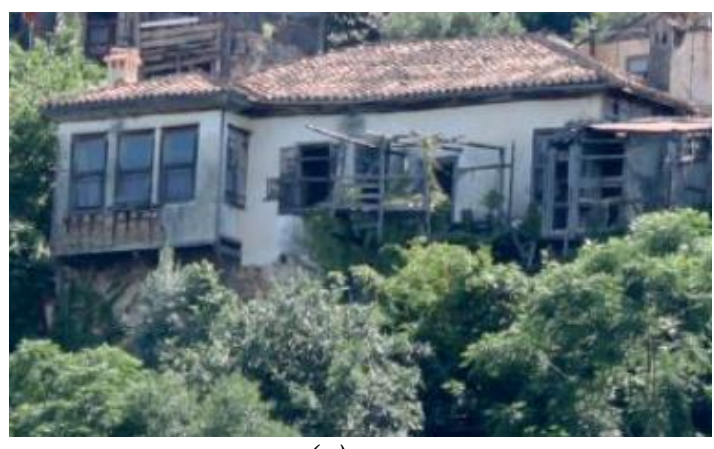

(a)

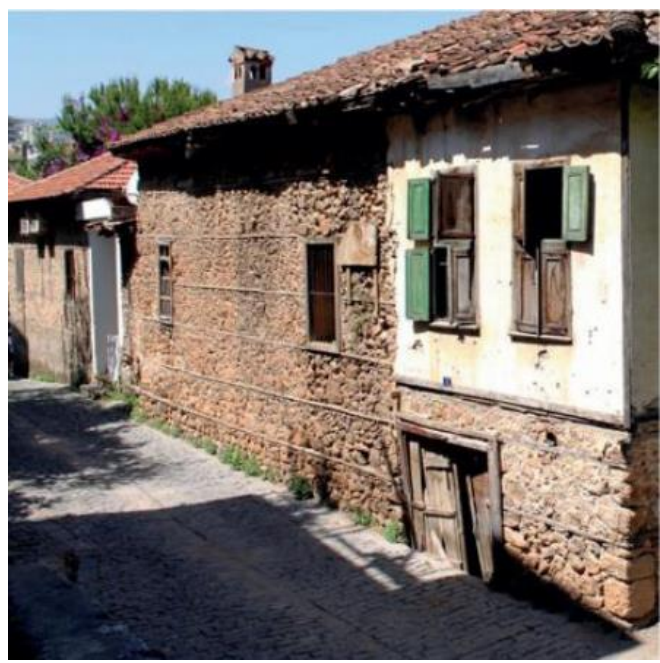

(c)

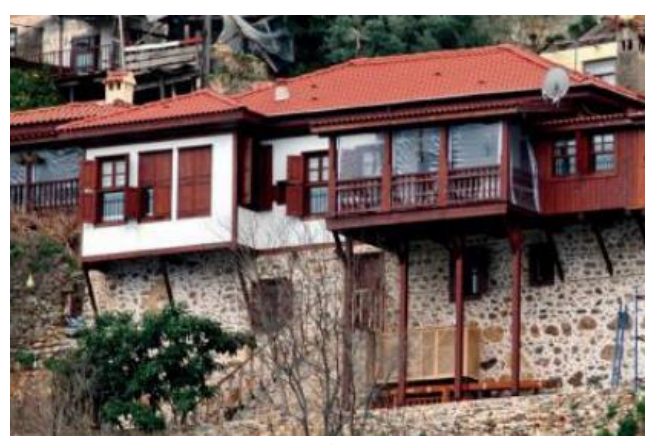

(b)

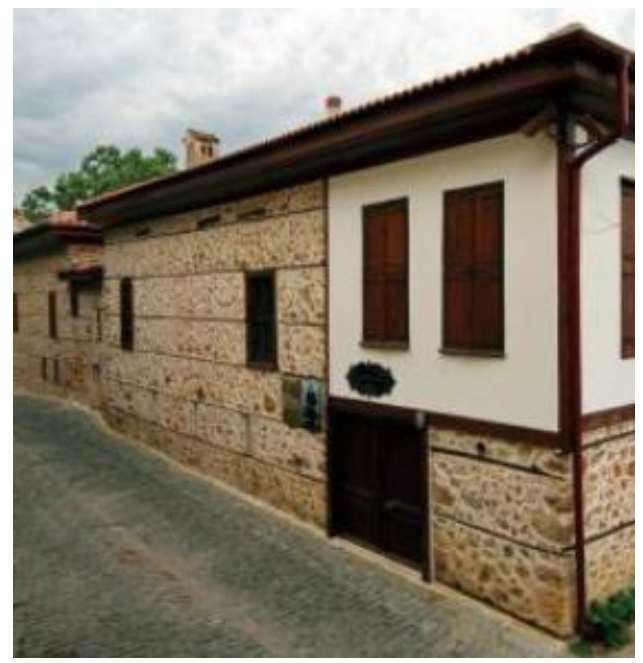

(d)

Şekil 20. Ali Gürses Konutu (a) Onarım öncesi ön cephe, (b) Onarım sonrası ön cephe, (c) Onarım öncesi arka cephe, (d) Onarm sonrast arka cephe.

\section{H. NAZIF KÖK KONUTU (263 ADA- 70 PARSEL)}

İşlev değişikliği yapılmadan onarılıp kullanılan diğer geleneksel konut ise birinci yerleşim alanı ile ikinci yerleşim alanı arasında bulunan Nazif Kök Konutu'dur (Şekil 21-22).

Yapının özgün plan şeması, dış sofalı plan tipindedir. Zemin kat ile üstündeki bir kattan meydana gelmektedir. Özgün planında zemin katta avlu, 2 gedey, 2 oda ve bir hela çukuru vardır. Avludan 2 farklı merdivenle üst kata çıkılmaktadır. Üst katta hayat, hela, abdestlik, çağnişir, büyük içeri, küçük içeri ve çardak mekanları vardır. Avludan çıkılan merdivenler ile üst katta hayata ulaşılmaktadır.

Yapının restorasyondan sonraki halinde zemin katta gedeylerden birisi + hela çukuru $\rightarrow$ mutfak mekanına dönüştürülmüştür. Girişin yanındaki oda $\rightarrow$ oturma odasına, diğer gedey ve oda $\rightarrow 2$ ayrı yatak odası haline getirilmiştir. $\mathrm{Bu}$ iki yatak odasının arasına, bu odalara hizmet veren 2 banyo yapılmıştır. Üst kattaki hela ve abdestlik birleştirilerek $\rightarrow$ depo yapılmıştır. Küçük içeri $\rightarrow$ mutfak, büyük içeri $\rightarrow$ yatak odası haline getirilmiştir. Küçük içeri ile büyük içerinin arasına banyo yapılmış, banyo, yatak odasına hizmet etmektedir. Çağnişir ve çardak korunmuştur. Kullanıcı istekleri doğrultusunda yapılan tüm değişiklik ve onarımlar esnasında özgün teknik ve yap1 malzemesi kullanılmıştır. Cephelerin özgünlüğü büyük ölçüde korunmuştur. 


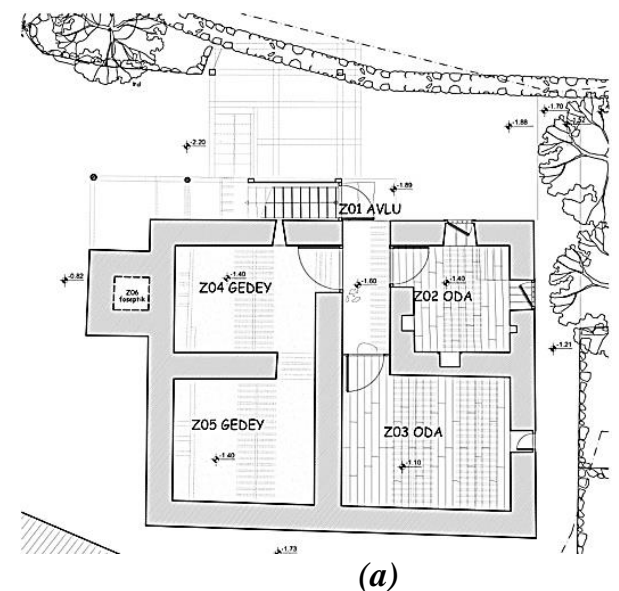

(a)

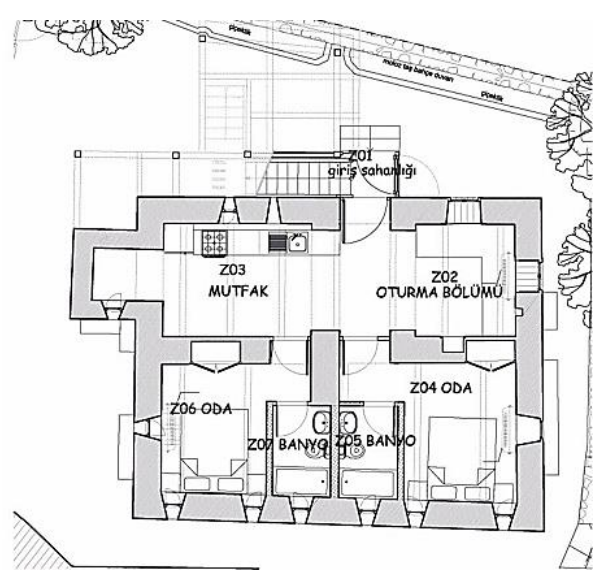

(b)

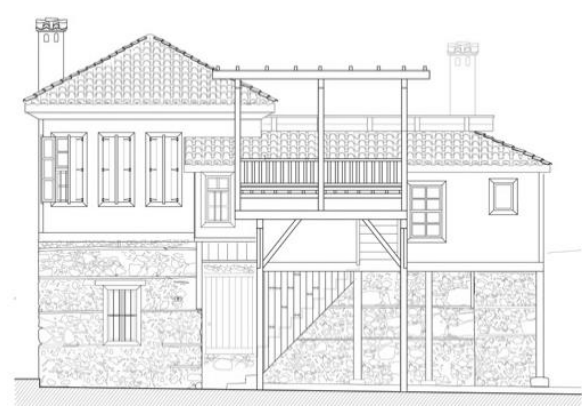

(e)

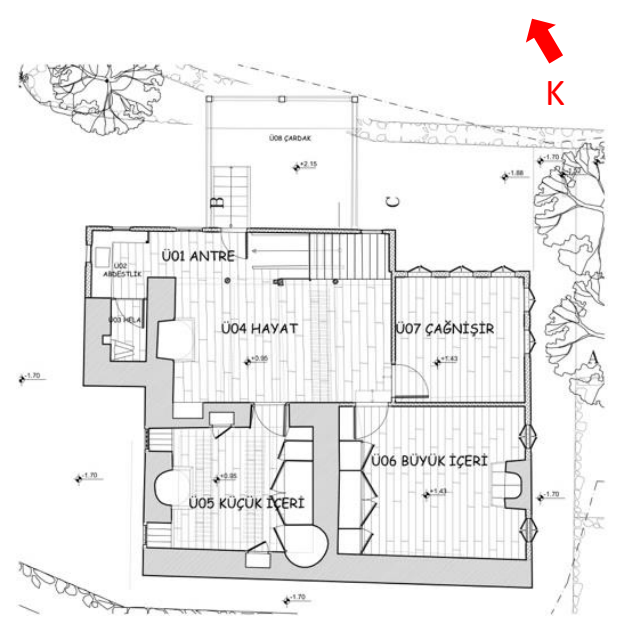

(b)

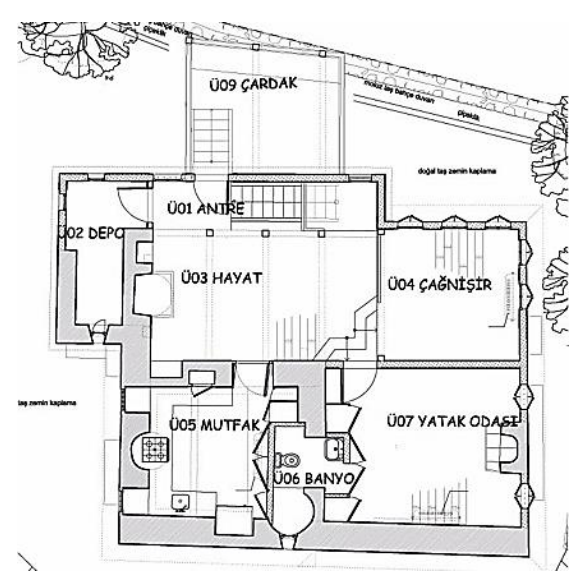

(d)

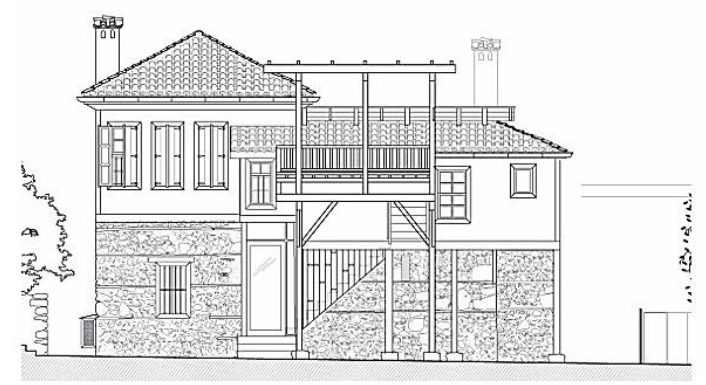

(f)

Şekil 21. Nazif Kök Konutu (a) Restitüsyon-Zemin kat planı, (b) Restitüsyon-1. kat planı, (c) Restorasyon-Zemin kat planı, (d) Restorasyon-1. kat planı,

(e) Restitüsyon-Ön cephe, (f) Restorasyon-Ön cephe [14]. 


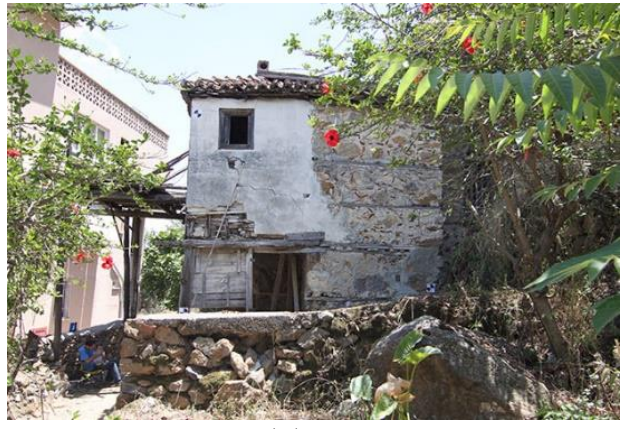

(a)

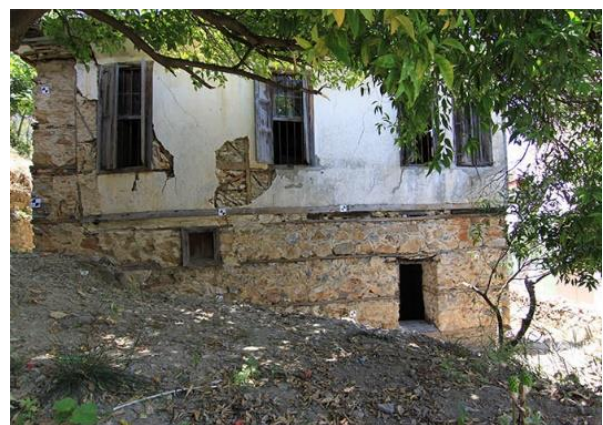

(c)

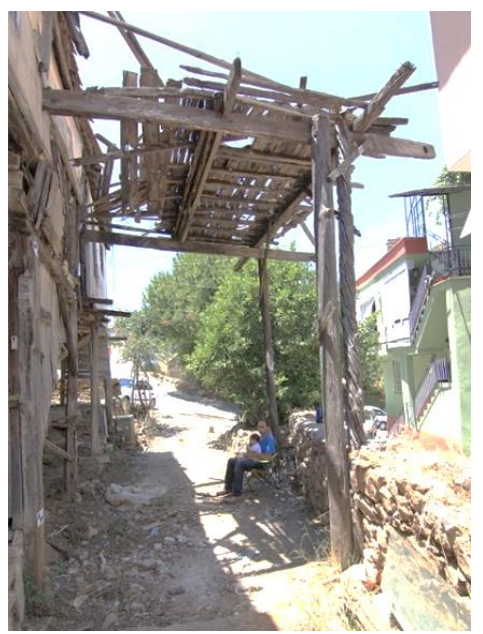

(e)

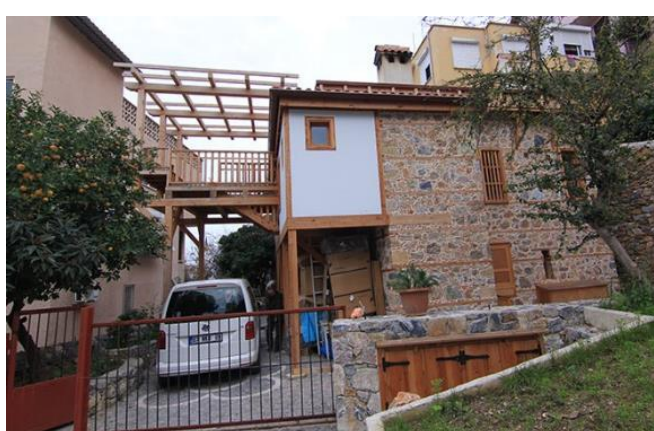

(b)

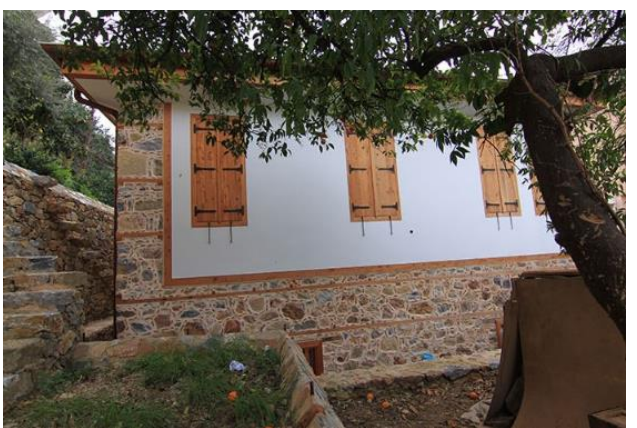

(d)

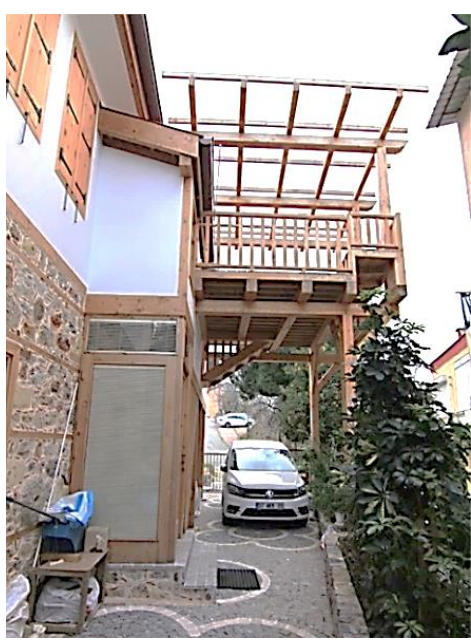

$(f)$

Şekil 22. Nazif Kök Konutu (a) Onartm öncesi săg yan cephe, (b) Onartm sonrast să̆ yan cephe, (c) Onartm öncesi sol yan cephe, (d) Onarım sonrası sol yan cephe, (e) Onarım öncesi çardak, $(f)$ Onarım sonrasl çardak.

\section{SONUC VE DEĞERLENDIRME}

Alanya'da ondokuzuncu yüzyılın başlarında çok sayıda geleneksel konut varken günümüze pek azı ulaşabilmiştir. Bu konutların birçoğu günümüz yaşam koşullarının hızına adapte edilmediği için ya terk edilmiştir ya da hatalı imar kararları, rant, bakımsızlık gibi nedenlerle yıkılmıştır.

Günümüze ulaşabilenlerin turizm sektörü üzerindeki çekici etkisi anlaş1lmış, önce tescillenip sonra turizm ve ticaret işlevleriyle donatılarak restore edilmeye başlanmıştır. Ancak geleneksel konutların yapıldıkları dönemdeki sosyo-ekonomik durumu ve yaşam biçimini yansıtan tarihi belge niteliğinde oldukları halen tam olarak anlaşılamamıştır. Yeniden işlevlendirme adı altında yapılan değişiklikler 
geleneksel konutların özgünlüklerinden kayıplar verilmesine neden olmuştur ve olmaya devam etmektedir.

Alanya'da yeniden işlevlendirilerek kullanılan geleneksel konutlar incelendiğinde, ofis amaçlı kullanılan konutların plan şemasının ve cephelerinin korunduğu ancak hayvanlar için ayrılan barınak bölümlerinin özgün iç mekân donatılarının yok edildiği görülmüştür. Konaklama amaçlı yani butik otel olarak yeniden işlevlendirilen konutlarda ise plan şemasının tamamen değiştirildiği anlaşılmaktadır. Bunun nedeni çok sayıda odaya ve her odada banyoya sahip olma çabasıdır. Ayrıca bütün odalara gün ışığı ve doğal hava sağlamak amacıyla cephelerdeki sağır duvarlarda pencereler açılmıştır. $\mathrm{Bu}$ müdahale, cephelerin de özgünlügünü kaybetmesine neden olmuştur. Geleneksel konutlardan oluşan tarihi dokunun cazibesi nedeniyle bu yapılarda konaklamayı tercih eden turistlerin, plan ve cephe özgünlügü tamamen bozulmuş konutlarda misafir edilmesi, ülkemiz açısından koruma ve turizm ikilemi arasında çelişkili bir durumdur. Plan şeması değiştirilirken yığma yapım tekniğinde inşa edilmiş olmaları nedeniyle hem bölücü hem taşıyıcı görevi bulunan iç duvarların tamamen kaldırılması, geleneksel konutları strüktürel açıdan da zayıflatmaktadır. Restoran-kafe olarak yeniden işlevlendirilen geleneksel konutlarda, mevcut mutfak mekanları genişletilmiş, mutfak sayısı artırılmış ve üst katlarda da bazı odalar mutfağa dönüştürülmüştür. Bu mekanlarda yoğun nem ve 1sıya maruz kalan geleneksel yapım malzemelerinin de çeşitli bozulmalara açık hale geldiği düşünülmektedir. Ayrıca bu yapılarda ahşap malzemenin yapım sisteminin önemli bir bölümünü oluşturduğu düşünülürse, yangına karşı ciddi önlemlerin alınması gereklidir. Restoran olarak işlevlendirilen konutta aynı anda çok sayıda müşteriye yemek yeme imkânı sunma amacı ile geniş bir yemek salonu elde etme müdahalesi olmuştur. Bu nedenle bir oda, sofa ve merdiven boşluğu birleştirilmiş, merdiven başka bir yere taşınmış ve yemek salonunun önüne bir teras eklenmiştir. İç mekânda yapılan bu değişimler doğal olarak cepheye de yansımış, plan şeması ile cepheler de özgünlüğünü kaybetmiştir. Özgün işlevi değiştirilmeden yine konut işlevinde kullanılmak üzere restore edilmiş yapılar incelendiğinde ise her iki örnekte de bütün odalara banyo eklenmiş olduğu dikkati çekmektedir. $\mathrm{Bu}$ müdahale, kullanıcılarının aile yaşamlarında gerçekten böyle bir ihtiyaçları var mı yoksa günümüzde ya da gelecekte yapıyı otel olarak işletme fikrini mi taşıdıkları sorusunu akla getirmektedir. Cephelerde kısmen özgünlük korunmuş, yıkık kısımlarda geleneksele öykünen yeni tasarımlar yapılmıştır. Ancak tüm müdahaleler göz önünde bulundurulduğunda özgün işlevi ile kullanılacağ1 beyan edilen konutlarda da plan şeması ve cephe özgünlüğü korunmamıştır.

Alanya'da yeniden işlevlendirilen geleneksel konut yapılarının özgünlük açısından yapılan analizlerinden şu genellemeleri yapmak mümkündür. 2863 sayılı kanunun da verdiği yetkiyle geleneksel konut yapıları bir kabuk olarak kabul edilip, başta plan şemaları olmak üzere strüktür, malzeme, renk ve peyzaj gibi birçok özgün mimari özelliklerini kaybetmektedir. İncelenen örneklerden sadece kültür müdürlüğü ve bir dernek tarafindan ofise dönüştürülen konutların özgünlüğü korunmuştur. Diğer işlevlerle donatılan bütün yapılar önemli derecede özgünlüklerini kaybetmişlerdir. Özgün işlevi ile kullanılmak üzere restore edilen konutlarda da otele dönüştürülenlerle aynı müdahaleleri görmek, geleneksel konutların özgün işlevleri ile kullanılmalarının dahi özgünlüklerini korumak için yeterli bir çözüm olmadığını göstermektedir.

$\mathrm{Bu}$ nedenle ülkemizdeki koruma ile ilgili yasal normların geleneksel konut yapılarını plan şeması, strüktür, malzeme, cephe, renk, peyzaj, yakın çevre, bulunduğu doku bütünü, kent ile ilişkisi vb. birçok yönden özgünlüğü ile korunmasını sağlayacak şekilde düzenlenmesi gerekir. Yeni verilen işlev her ne olursa olsun, yapıların özgünlügüne zarar verilmemelidir. Yeniden işlevlendirmenin tarihi binaların yıkımdan kurtarılması için bir amaç değil, bir araç olduğu unutulmamalıdır. Özellikle otel, restoran gibi çok farklı plan düzenlemelerini gerektiren işlevler için boş parsellerde yeni yapı tasarımları düşünülmelidir. Nitekim tarihi çevrede yeni yapı tasarımı konusu, dünyada birçok tasarımcı ve korumacı mimarların beyin fırtınası yaptığı önemli konulardan birisidir. 


\section{KAYNAKLAR}

[1] E.F. Alioğlu. (1991). Geleneksel yapı elemanları. [Çevrimiçi]. Erişim: https://www.scribd.com/document/433144255/GELENEKSEL-YAPI-ELEMANLARI

[2] D. Zeybekoğlu, "Edirne geleneksel konut mimarlığını etkileyen sosyo-kültürel faktörlerin incelenmesi," Yüksek Lisans tezi, Fen Bilimleri Enstitüsü, Trakya Üniversitesi, Edirne, Türkiye, 2005.

[3] B.M. Feilden ve J. Jokilehto. (1998). Management guidelines for world cultural heritage sites. [Online]. Available: https://www.iccrom.org/sites/default/files/201802/1998_feilden_management_guidelines_eng_70071_light_0.pdf

[4] ICOMOS. (1994, Nov 1-6). The Nara document on authenticity. [Online]. Available: https://www.icomos.org/charters/nara-e.pdf

[5] B. Eroğlu ve E. Yaldız, "Kültür mirasının sürekliliği için anıtsal binaların yeniden kullanılması bağlamında Ermenek Tol Medrese," Selçuk Üniversitesi Sosyal Bilimler Enstitüsü Dergisi, s. 15, ss. 315-340, 2006.

[6] D. Aydın ve E. Yaldız, "Yeniden kullanıma adaptasyonda bina performansının kullanıcılar üzerinden değerlendirilmesi," Orta Doğu Teknik Üniversitesi Mimarlık Fakültesi Dergisi, c. 27, s. 1, ss. $1-22,2010$.

[7] G. Urak, "Kullanımda değerlendirme: Ankara Kaleiçi restorasyon/işlevsel dönüşüm uygulamaları ve Ankara halk1," Hacettepe Üniversitesi Edebiyat Fakültesi Dergisi, c. 19, s. 1, ss. 45$62,2002$.

[8] O. Atak ve A. Atak. (2019, 2 Ekim). Antalya İli, Alanya İlçesi, Dim Çayı, kıyı koruma yapıları (mahmuz) 1/5000 ölçekli nazım imar planı plan açıklama raporu [Çevrimiçi]. Erişim: https://webdosya.csb.gov.tr/db/antalya/duyurular/rapor_5000-20191002154230.pdf

[9] Antalya Valiliği Çevre Ve Şehircilik İl Müdürlüğü. (2018). Jeolojik - jeoteknik etüt çalışmaları. [Online]. Available: http://antalya.csb.gov.tr/jeolojik---jeoteknik-etut-calismalari-i-85709

[10] Ö. Göncü, “Alanya Hasanağalar konağı restorasyon önerisi,” Yüksek Lisans tezi, Mimarlık Bölümü, ODTÜ, Ankara, Türkiye, 2012.

[11] H. Şener, Alanya'da Geleneksel Konutlar, İstanbul, Türkiye: İTÜ Mimarlık Fakültesi Bask1 Atölyesi, 1984.

[12] N. Hacikura, "Alanya'da Müftüoğlu evi restorasyon projesi," Yüksek Lisans tezi, Fen Bilimleri Enstitüsü, İTÜ, İstanbul, Türkiye, 2002.

[13] Mimar Şükran Ural, Arşivi, Alanya, 2012.

[14] Yüksek Mimar Emine Cimrin Koçak, Arşivi, Alanya, 2018.

[15] Alanya Belediyesi, Arşivi, Alanya, 2012. 